\title{
The Custody Crucible: The Development of Scientific Authority About Gay and Lesbian Parents
}

\author{
MARIE-AMÉLIE GEORGE
}

In 1974, gay father Bruce Voeller sought visitation with his three children after divorcing his wife. The New Jersey family court held a six day trial that centered on expert witness testimony as to whether Voeller's homosexuality would be detrimental to his children. Drs. Richard Green and John Money testified on Voeller's behalf, whereas Voeller's ex-wife called Dr. Richard Gardner, who concluded that " "the total environment to which the father exposed the children could impede healthy sexual development in the future." In his opinion, which imposed strict limitations on visitation, the judge focused on the opposition within the American Psychiatric Association (APA) over the decision to declassify homosexuality as a mental illness, reasoning that psychiatrists' inability to agree on how to define or classify homosexuality indicated that it was impossible to know what effect Voeller's homosexuality would have on his children. The court consequently concluded that the medical controversy, combined with "the immutable effects which are engendered by the parent-child relationship, demands that the court be most hesitant in allowing any unnecessary exposure of a child to an environment which may be

Marie-Amélie George is an Associate in Law, Columbia Law School and a PhD candidate in history at Yale University <mgeorge@law.columbia.edu>. She is indebted to Joanne Meyerowitz, Reva Siegel, George Chauncey, John Witt, Doug NeJaime, and Karen Tani for their thoughtful comments on drafts. She also thanks the anonymous readers for the journal, whose suggestions improved this article immensely. This project was made possible through the generous support of the Yale Fund for Lesbian and Gay Studies and the Cornell University Phil Zwickler Memorial Research Grant. 
deleterious." The court imposed visitation restrictions to prevent the children from being in "any homosexual related activities," which included prohibiting Voeller from ever introducing his partner to the children. ${ }^{2}$

Voeller's trial illustrates the extent to which scientific authority concerning homosexuality became central to gay father and lesbian mother custody cases, which were litigated in increasing numbers after the APA's 1973 decision to declassify homosexuality as a mental illness. Although a small number of lesbian mothers and gay fathers sought custody prior to the declassification, the APA's decision removed a barrier that had prevented most homosexual parents from asserting their rights in court. As Daniel Rivers has carefully documented, lesbian mothers and gay fathers became increasingly visible in the 1970s, asserting their rights in court and building support networks as they pressed their claims. ${ }^{3}$ Even as courts increasingly acknowledged that gay men and women were not mentally ill, the APA declassification raised a new set of questions. Although the APA decision established that gay men and lesbians were not inherently pathological, it did not address the psychological impact that homosexual adults could have on children's psychosexual development. This became a crucial issue in lesbian and gay custody cases litigated after 1973, with courts questioning whether children raised by gays and lesbians would be able to develop prescribed gender identities and heterosexual orientations. ${ }^{4}$

At the same time as the APA's declassification made it increasingly possible for lesbian mothers to seek custody of their children, the fathers' rights movement made gains in overturning the "tender years" doctrine that presumptively gave custody to mothers. This movement emerged as

1. In re J.S. \& C., 324 A.2d 90, 97 (N.J. Super. Ct. Ch. Div. 1974); and "State Court Rules Gay Activism Harmful to Children," Psychiatric News, September 4, 1974, Box 88, Folder 17, National Gay and Lesbian Task Force Records, Collection Number 7301, Carl A. Kroch Library, Cornell University (hereafter NGLTF).

2. In re J.S. \& C., 324 A.2d at 97.

3. Daniel Winunwe Rivers, Radical Relations: Lesbian Mothers, Gay Fathers, and Their Children in the United States since World War II (Chapel Hill: University of North Carolina Press, 2013).

4. Ibid., 67-72; Carlos A. Ball, The Right to be Parents: LGBT Families and the Transformation of Parenthood (New York: New York University Press, 2012), 27; Susan Gluck Mezey, Gay Families and the Courts: The Quest for Equal Rights (Lanham, MD: Rowman \& Littlefield, 2009), 17; Kimberly D. Richman, Courting Change: Queer Parents, Judges, and the Transformation of American Family Law (New York: New York University Press, 2009), 28, 48, 53; Nancy D. Polikoff, "Raising Children: Lesbian and Gay Parents Face the Public and the Courts," in Creating Change: Sexuality, Public Policy, and Civil Rights, ed. John D'Emilio, William B. Turner, and Urvashi Vaid (New York: St. Martin's Press, 2000), 312; and Laura Briggs, Somebody's Children: The Politics of Transracial and Transnational Adoption (Durham, NC: Duke University Press, 2012), 248-49. 
states adopted no-fault divorce systems, beginning with California in 1970, leading divorce rates to reach fifty percent by $1980 .{ }^{5}$ Employing the feminist rhetoric of equality that had supported divorce law reform, fathers' rights groups successfully challenged judicial standards, leading family law courts to base their determinations on the gender-neutral "best interests of the child." 6 In 1973, a New York family court declared the "tender years" presumption unconstitutional, and courts around the country quickly followed suit. ${ }^{7}$ Lesbian mothers were therefore beginning to seek custody at a time when judges were no longer committed to a maternal preference in making their determinations.

Lesbian mothers and gay fathers were consequently fighting for custody during a period of shifting legal and scientific landscapes, creating an opportunity for social science research to effectuate legal change. ${ }^{8}$ As Suzanne Goldberg has argued, courts embracing new normative commitments will often rely upon expert evidence to reject traditional rationales for restricting minority rights. ${ }^{9}$ Scientists often undertook their studies with the express purpose of helping gay fathers and lesbian mothers in their custody battles, skirting the line between neutral science and advocacy. They consequently focused their research on whether a parent's homosexuality would result in children growing up to be homosexual themselves, one of the most consistently raised objections to lesbian mother and gay father custody claims. ${ }^{10}$ As this article demonstrates, the APA decision

5. Carlos A. Ball, Same Sex Marriage and Children: A Tale of History, Social Science, and Law (New York: Oxford University Press, 2014), 59-60; and Robert O. Self, All in the Family: The Realignment of American Democracy Since the 1960s (New York: Hill \& Wang, 2012), 328.

6. Martha Fineman, "Dominant Discourse, Professional Language, and Legal Change in Child Custody Decisionmaking," Harvard Law Review 101 (1988): 739-40.

7. Watts v. Watts, 350 N.Y.S.2d 285 (1973); and Deborah Dinner, "The Divorce Bargain: The Fathers' Rights Movement and Family Inequalities," Virginia Law Review 102 (2016): $115 \&$ n. 171 .

8. Courts are a vital part of the social context of social scientific inquiries, which render certain research questions more salient than others. David S. Caudill and Lewis H. LaRue, No Magic Wand: The Idealization of Science in Law (Oxford: Rowman \& Littlefield Publishers, 2006), 28, 42; Jennifer L. Mnookin, "Scripting Expertise: The History of Handwriting Identification Evidence and the Judicial Construction of Reliability," Virginia Law Review 87 (2001): 1744; and Sheila Jasanoff, The Fifth Branch: Science Advisers as Policymakers (Cambridge, MA: Harvard University Press, 1990), 13.

9. Suzanne Goldberg, "Constitutional Tipping Points: Civil Rights, Social Change, and Fact-Based Adjudication," Columbia Law Review 106 (2006): 1975.

10. Donna J. Hitchens and Ann G. Thomas, Lesbian Mothers and Their Children: An Annotated Bibliography of Legal and Psychological Materials (San Francisco: Lesbian Rights Project, 1980), Box 123, Folder 12, Phyllis Lyon and Del Martin Papers, Collection Number 1993-13, GLBT Historical Society (hereafter Lyon/Martin Papers), i. 
to declassify homosexuality as a mental illness did not sever the relationship between scientific authority and gay rights adjudication, which had deleterious consequences for gay men and women for much of the twentieth century. ${ }^{11}$ Instead, it produced a new contest in the courts over the connection between gay rights and psychological science, one that would ultimately benefit gay men and lesbians.

The work of these researchers not only served to protect the individual rights of gay and lesbian parents in court, but also to change the way in which other mental health professionals understood the impact of gay fathers and lesbian mothers on their children. The major psychological explanations for homosexuality in the 1970s and 1980s emphasized the importance of early age gender role development in determining sexual orientation; without evidence to the contrary, most mental health professionals assumed that parental homosexuality would prevent children from learning the appropriate gender roles that would lead to a heterosexual orientation. Although the work of these scientists, which stressed that the children of lesbian mothers and gay fathers would become heterosexual, provided valuable evidence for gay and lesbian litigants, these studies also perpetuated the notion that homosexuality was an undesirable outcome, creating a double-edged sword for litigants.

The centrality of expert authority in gay father and lesbian mother cases reflected a contemporary change in courts' relationship to social science research. In the wake of the 1954 Brown v. Board of Education decision, in which the Supreme Court famously cited seven social science studies to establish that segregation harmed black children, courts increasingly drew on social science evidence in adjudicating civil rights claims. ${ }^{12}$ Whereas previous reform movements, particularly in the Progressive Era, had deployed social science evidence to effectuate legal change, these efforts had dissipated by the civil rights era, when lawyers once again began introducing social science in the courts to support their claims. ${ }^{13}$ In the

11. Margot Canaday, The Straight State: Sexuality and Citizenship in Twentieth-Century America (Princeton: Princeton University Press, 2009), 220-21, 229-32; and Marc Stein, Sexual Injustice: Supreme Court Decisions from Griswold to Roe (Chapel Hill: University of North Carolina Press, 2010), 175-80, 183-89.

12. Brown v. Board of Education, 347 U.S. 483, 494 n.11 (1954); and Amy Rublin, "The Role of Social Science in Judicial Decision Making: How Gay Rights Advocates Can Learn from Integration and Capital Punishment Case Law," Duke Journal of Gender Law \& Policy 19 (2011): 189-90.

13. Social science was also central to policymaking, particularly in efforts to reform welfare. Marisa Chappell, The War on Welfare: Family, Poverty, and Politics in Modern America (Philadelphia: University of Pennsylvania Press, 2010), 35-39, 52-58; and Premilla Nadasen, Welfare Warriors: The Welfare Rights Movement in the United States (New York: Routledge, 2005), 143-46. 
1960s and 1970s, the Law and Society movement emerged "as a vehicle to capitalize on the promise that social science could be enlisted in the pursuit of legal reform. The movement was founded on something of a paradox, an assumption that neutral and objective research would naturally support a progressive reform agenda." ${ }^{14}$ Although social science research would prove to have a limited effect in cases involving race discrimination, it did help gay and lesbian parents assert their rights in court. ${ }^{15}$ Gay fathers and lesbian mothers employed social science evidence to demonstrate that their sexual orientation would not negatively impact their children, convincing courts to uphold their custody rights. Although there were important regional differences in how courts adjudicated custody claims, such that gay and lesbian parents were primarily successful in traditionally liberal states, social science evidence was central to decisions granting these parents custody. Gay and lesbian advocacy groups recognized the importance of social science evidence in custody cases, working to recruit expert witnesses and disseminating research findings to gay fathers and lesbian mothers embroiled in custody disputes. Unlike other instances in queer legal history, which Felicia Kornbluh, Marc Stein, and Margot Canaday have shown were characterized by legal institutions marginalizing gays and lesbians, gay fathers and lesbian mothers benefited from this shift in judicial practice. ${ }^{16}$

As these pro-gay parenting research studies became accepted in both scientific circles and courts, conservative researchers began crafting their own studies in response. These researchers also sought to intervene in political and legal battles over gay rights, framing their work to address gay civil rights claims. Building upon the work of Robert Self, whose recent monograph emphasizes the political, economic, and religious elements of gay rights battles of the 1970s, this article demonstrates that scientific knowledge was also a crucial dimension of debates over gay rights. ${ }^{17}$ Because conservative research was responding to the successes of its liberal counterpart, anti-gay and lesbian parenting studies did not develop until the late 1980 s, although this was still several years before the conservative legal movement began addressing sexual orientation. While the 1970s are known for the resurgence of the conservative right, and prominent

14. Rublin, "The Role of Social Science in Judicial Decision Making," 183-84; and Rachel F. Moran, "What Counts as Knowledge?, A Reflection on Race, Social Science, and the Law," Law and Society Review 44 (2010): 516.

15. Moran, "What Counts as Knowledge?," 527.

16. Felicia Kornbluh, "Queer Legal History: A Field Grows Up and Comes Out," Law and Social Inquiry 35 (2011): 539-40; Canaday, The Straight State, 220-21, 229-32; and Stein, Sexual Injustice, 175-80, 183-89.

17. Self, All in the Family, 341-42, 349-51. 
advocates like Anita Bryant and Phyllis Schlafly employed the specter of gay families to argue against liberal legal reforms, conservative law groups did not become involved in battles over gay and lesbian families until much later. ${ }^{18}$ Conservative litigation firms, which proliferated in the 1970 s and 1980 s, focused on protecting free enterprise, primarily by opposing environmental regulations that impinged on business interests. ${ }^{19}$ Two of the most well-known and effective conservative public interest law firms litigating social issues, the Institute for Justice and the Center for Individual Rights, were not formed until the early 1990s. ${ }^{20}$ The battles over the family, which were central to the political debates of the 1970s, were not waged in the courtroom until the 1990s. ${ }^{21}$

The development of social science research in lesbian mother and gay father custody cases demonstrates the extent to which courtroom debates extend beyond the individual cases being adjudicated. Scholars such as Michael Klarman have argued against litigation as a tool for social change, highlighting the limited capacity of courts to shape the social forces outside their doors, although other historians have argued that court decisions have proved to be crucial elements in meaningful civil rights reform. ${ }^{22}$ Douglas NeJaime, on the other hand, has focused on how litigation losses can provide important opportunities for social movements, as they galvanize interest in promoting rights. ${ }^{23}$ This article provides a different interpretation of how courts can contribute to social change. Courts in the 1970s helped set the agenda for a new generation of social scientific research on the psychological significance of homosexuality in American life, reshaping scientific

18. Reva B. Siegel, "Constitutional Culture, Social Movement Conflict and Constitutional Change: The Case of the de facto ERA," California Law Review 94 (2006): 1390, 1400402; and Gillian Frank, "'The Civil Rights of Parents': Race and Conservative Politics in Anita Bryant's Campaign against Gay Rights in 1970s Florida," Journal of the History of Sexuality 22 (2013): 135-36.

19. Jefferson Decker, "Lawyers for Reagan: The Conservative Litigation Movement and American Government, 1971-1987" (PhD diss., Columbia University, 2009); and Ann Southworth, Lawyers of the Right: Professionalizing the Conservative Coalition (Chicago: University of Chicago Press, 2008), 152.

20. Ilya Somin, "Lessons from the Rise of Legal Conservatism," Harvard Journal of Law and Public Policy 32 (2009): 421.

21. Self, All in the Family, $6,8$.

22. Michael J. Klarman, From the Closet to the Altar: Courts, Backlash, and the Struggle for Same-Sex Marriage (New York: Oxford University Press, 2013), 167-69; Michael J. Klarman, From Jim Crow to Civil Rights: The Supreme Court and the Struggle for Racial Equality (New York: Oxford University Press, 2004), 385, 435; and Tomiko Brown-Nagin, Courage to Dissent: Atlanta and the Long History of the Civil Rights Movement (New York: Oxford University Press, 2011), 135.

23. Douglas NeJaime, "Winning Through Losing," Iowa Law Review 96 (2011): 945. 
literature and legal debates about the place of gay men and women in the American family.

Custody cases helped spur scientific inquiry into the impact of parental homosexuality on children's sexual orientation and gender identity, with courts across the United States becoming critical arenas for the articulation of medical knowledge and forums for scientific debates on homosexuality. These cases contributed to the development of scientific studies that would aid a social movement, becoming a crucial part of the struggle for gay rights and social equality. They would also result in the later production of anti-gay and lesbian research, which buttressed the claims of gay rights opponents. Anti-gay rights groups did not coalesce around custody claims, but conservative scientists undertook research in response to the liberal studies being advanced in custody cases, which would become central to other gay rights battles. Drawing upon published appellate and trial court opinions, unpublished trial court documents and transcripts, gay and lesbian periodicals, national and local newspapers, personal correspondence, oral history interviews, and other primary sources, this article explains how these research agendas developed, establishing how custody disputes served as a crucible for the creation of and contests over scientific authority on gay and lesbian families.

\section{Emergence of Lesbian and Gay Custody and Visitation Cases}

Lesbian and gay parents did not begin asserting their custody rights solely because of the APA's declassification, but rather these cases were part of the same impulse to change the social status of homosexuals in America that led to the diagnostic change. The explosion of gay activism in the 1970s not only forced the mental health community to reconsider its position on homosexuality as a mental illness, but also empowered homosexual parents to come out, divorce their spouses, and assert their rights in court. ${ }^{24}$ Prior to the gay liberation movement, and the increasing acceptance of lesbians and gays in American society, heterosexual parents often blackmailed their homosexual ex-spouses into relinquishing custody by threatening to disclose the gay parent's sexual orientation to family, friends, and coworkers. ${ }^{25}$ Even as the gay rights movement gained traction,

24. Marc Stein, Rethinking the Gay and Lesbian Movement (New York: Routledge, 2012), ch. 3-4; Self, All in the Family, 222-23, 230-31; Rivers, Radical Relations, 5354; and Klarman, From the Closet to the Altar, 17-18, 22-26.

25. Rhonda Rivera, "Where We Stand: Gay Parent," Metro Gay News (Detroit, MI), February 1977, Box 88, Folder 17, NGLTF. 
most Americans still viewed homosexuality as incompatible with childrearing, allowing non-gay parents to continue to manipulate their former spouses. ${ }^{26}$ The conservative movement's emphasis on "traditional family values," a term that encompassed both the idealization of the heterosexual nuclear family and strict adherence to gender roles, served as an important rhetorical strategy to oppose gay rights, and demonstrates the strong social opposition to gay parents in many parts of the country. ${ }^{27}$

The gay liberation movement made these custody cases possible in other, more practical ways. Lesbian and gay rights organizations kept lists of sympathetic attorneys and expert witnesses, as well as helping to raise funds for the substantial costs associated with litigation. Lesbian mother groups also organized defense funds for particular cases, holding benefit auctions, rallies, movie screenings, and other fundraising events, responding to the financial struggles that single women faced. ${ }^{28}$ The rise of lesbian mother organizations and communications networks made it possible for mothers unable to bear the financial burden of litigation to obtain monetary support from supportive women around the country. ${ }^{29}$

It is important to note that many of the women fighting for custody were not active in lesbian rights organizations when they went to court, nor were they necessarily interested in promoting lesbian rights generally. They litigated custody cases to defend their families; their activism, more often than not, was incidental. These cases stressed their ability as mothers and the best interests of their children, and did not employ a rhetoric of rights, which would have been out of place in family court. ${ }^{30}$ Additionally, participating in gay liberation groups could be detrimental, as many judges saw this type of political activism as a basis for denying custody. ${ }^{31}$ At the same time, lesbian feminist groups did not necessarily see custody rights as an important part of lesbian activism, creating the need for lesbian mother groups. ${ }^{32}$

26. Jil Clark, "Lesbian Mother Fights Loss of Visiting Rights," Gay Community News (Boston), October 17, 1981, Box 88, Folder 19, NGLTF.

27. Self, All in the Family, 6, 10, 309-11, 349, 362, 369; Dominic Sandbrook, Mad as Hell: The Crisis of the 1970s and the Rise of the Populist Right (New York: Anchor Books, 2011), 352-53; and Elaine Tyler May, Homeward Bound: American Families in the Cold War Era, rev. ed. (1988; repr., New York: Basic Books, 2008), 7-8, 13-14, 91-94.

28. Rivers, Radical Relations, 82-86.

29. Martin Meeker, Contacts Desired: Gay and Lesbian Communications and Community, 1940s-1970s (Chicago: University of Chicago Press, 2006), 227; and Rivers, Radical Relations, 83.

30. Richman, Courting Change, 95-96.

31. "State Court Rules Gay Activism Harmful to Children"; and Rivers, Radical Relations, 65-66.

32. Rivers, Radical Relations, 106; and Self, All in the Family, 233. 
To analyze the role of mental health theories in lesbian and gay custody and visitation disputes, this article draws on 212 cases litigated between 1973 and 1998, all of which involved women and men who had children while in a heterosexual marriage. ${ }^{33}$ These cases represent a fraction of the total number of custody and visitation contests, as evidenced by the fact that, in its first three years, the Lesbian Mother National Defense Fund (LMNDF), a Seattle-based organization founded in 1974, provided assistance to mothers in 200 cases. ${ }^{34}$ Dykes and Tykes, a New York City lesbian mother group, received twenty-five to thirty-five calls a week from lesbian mothers afraid of losing their children during the first six months of the organization's existence, leading the group to form the East Coast Lesbian Mother Defense Fund in 1976. ${ }^{35}$ The majority of the cases in the data set involved lesbian mothers, in part because the principle of "tender years" impacted judicial determinations even after the "best interests of the child" standard became the cornerstone of family law in the early 1970 s. ${ }^{36}$ As a result of their sex and sexual orientation, gay fathers did not expect to succeed in custody suits, leading many gay fathers to focus instead on negotiating increased visitation with their ex-wives. ${ }^{37}$ Additionally, gay fathers did not escape the AIDS crisis of the early 1980s; San Francisco and Los Angeles gay father groups lost seventy to ninety percent of their members to AIDS. ${ }^{38}$

There are several reasons for the dearth of surviving case material, the primary being that family court decisions are typically unreported and sealed for the protection of the parties involved. Additionally, a significant number of disputes were settled prior to judicial adjudication, leaving no record. In 1979, Portland's Community Law Project, a public interest law firm, reported knowing of eighty to one hundred homosexual parent custody cases in the Portland metropolitan area that were settled out of court. The firm knew of only ten cases that went to trial. ${ }^{39}$ Movement

33. The vast majority - 156 cases - involved lesbian mothers seeking custody, whereas twelve cases involved lesbian mothers seeking visitation rights. In these visitation cases, the trial court precluded the mother from having any visitation with her child in one case, two outcomes are unavailable, and in the remainder visitation was granted, although the majority of the judges imposed restrictions preventing the mother's partner from being present when the children were at the mother's home.

34. Jody Laine, Shan Ottey, and Shad Reinstein, Mom's Apple Pie: The Heart of the Lesbian Mothers' Custody Movement (San Francisco: Frameline, 2006), DVD.

35. Rivers, Radical Relations, 86-87.

36. Ibid., 58. Only seventeen cases involved gay fathers seeking custody.

37. Ibid., 133.

38. Ibid., 133-35.

39. "Custody Rights of Gay Parents," The Fountain, March 1979, Box 88, Folder 17, NGLTF. 
lawyers recommended that homosexual parents settle their cases, believing that this would result in a better outcome ${ }^{40}$ Rosalie Davies, founder of the Philadelphia organization Custody Action for Lesbian Mothers (CALM), reported: "Most often, our goal is to stay out of court. The fewer cases we have going into court, the more we feel we're being successful. So we often ask a client to bargain, or give the father a little more visitation than she would normally want to give him, or to put up with some harassment." ${ }^{11}$ The data set also does not take into account the number of lesbian mothers who never sought custody or visitation, afraid of having their sexual orientation revealed or convinced that it was futile to attempt a court battle. Lesbian mother groups helped a number of women who went underground, fleeing with their children rather than facing the possibility of losing custody in court. ${ }^{42}$ The vast majority of the surviving case records involve white mothers, possibly because black lesbians were more likely to settle their disputes or go underground than take on court battles in which they would have to combat discrimination based on race, sexual orientation, and socioeconomic status. ${ }^{43}$ Additionally, the most publicized cases were those of white lesbian mothers battling their middle-class ex-husbands, leaving a dearth of newspaper accounts involving women of color. ${ }^{44}$

As the following tables indicate, what these cases reveal when aggregated is a mix of opinions ranging from discrimination to acceptance of lesbian and gay parents, not a steady progression in favor of lesbian mothers and gay fathers. Although lesbian mothers began winning cases more consistently after 1978, when research studies on lesbian mothers first emerged, these gains quickly faded. In the mid-to-late 1980s and early 1990 s, courts began ruling against lesbian mothers in greater numbers. The first table includes lesbian mother custody cases identified through all of my sources, including Westlaw. The second is limited to lesbian mother custody cases with published opinions available on Westlaw, collected using the search terms custody and either homosexual or gay or lesbian. Both tables demonstrate the same trends, although the decline in lesbian mother victories is starker when the data set is limited to published opinions.

40. "LDF Working for Lesbian Mothers," Seattle Gay News, February 17, 1978, Box 71, Folder 50, NGLTF; and Timothy Cook, "In the Best Interest of the Mother," Box 71, Folder 41, NGLTF.

41. Cook, "In the Best Interest of the Mother."

42. Kevin White, Not All Parents Are Straight (Full Frame Productions: San Francisco, CA, 1998), DVD.

43. Rivers, Radical Relations, 61-62.

44. Ibid., 61. 
Table 1. Lesbian Mother Custody Cases - All Sources

\begin{tabular}{lccccccc}
\hline Years & $\begin{array}{c}\text { Total } \\
\text { Cases }\end{array}$ & $\begin{array}{c}\text { Number } \\
\text { Won }\end{array}$ & $\begin{array}{c}\text { Percent } \\
\text { Won }\end{array}$ & $\begin{array}{c}\text { Number } \\
\text { Lost }\end{array}$ & $\begin{array}{c}\text { Percent } \\
\text { Lost }\end{array}$ & $\begin{array}{c}\text { Unknown } \\
\text { Result }^{\mathrm{i}}\end{array}$ & $\begin{array}{c}\text { Percent } \\
\text { Unknown }\end{array}$ \\
\hline $1973-1978$ & 46 & 22 & $47.8 \%$ & 20 & $43.5 \%$ & 4 & $8.7 \%$ \\
$1979-1985$ & 47 & 24 & $51.1 \%$ & 20 & $42.6 \%$ & 3 & $6.4 \%$ \\
$1986-1992$ & 29 & 10 & $34.5 \%$ & 17 & $58.6 \%$ & 2 & $6.9 \%$ \\
$1993-1998$ & 34 & 10 & $29.4 \%$ & 18 & $52.9 \%$ & 6 & $17.6 \%$ \\
All & 156 & 66 & $42.3 \%$ & 75 & $48.1 \%$ & 15 & $9.6 \%$ \\
\hline
\end{tabular}

Table 2. Lesbian Mother Custody Cases - Published Opinions

\begin{tabular}{lccccccc}
\hline Years & $\begin{array}{c}\text { Total } \\
\text { Cases }\end{array}$ & $\begin{array}{c}\text { Number } \\
\text { Won }\end{array}$ & $\begin{array}{c}\text { Percent } \\
\text { Won }\end{array}$ & $\begin{array}{c}\text { Number } \\
\text { Lost }\end{array}$ & $\begin{array}{c}\text { Percent } \\
\text { Lost }\end{array}$ & $\begin{array}{c}\text { Unknown } \\
\text { Result }^{\mathrm{i}}\end{array}$ & $\begin{array}{c}\text { Percent } \\
\text { Unknown }\end{array}$ \\
\hline $1973-1978$ & 16 & 7 & $43.8 \%$ & 9 & $56.3 \%$ & 0 & $0.0 \%$ \\
$1979-1985$ & 20 & 9 & $45.0 \%$ & 11 & $55.0 \%$ & 0 & $0.0 \%$ \\
$1986-1992$ & 17 & 4 & $23.5 \%$ & 10 & $58.8 \%$ & 3 & $17.6 \%$ \\
$1993-1998$ & 18 & 6 & $33.3 \%$ & 11 & $61.1 \%$ & 1 & $5.6 \%$ \\
All & 71 & 26 & $36.6 \%$ & 41 & $57.7 \%$ & 4 & $5.6 \%$ \\
\hline
\end{tabular}

i The courts in these instances remanded the cases for lower court adjudication; the final outcome is not available.

These tables suggest a different trajectory than that of the statements from activists and movement lawyers, who emphasized that ninety-eight percent of lesbian mothers lost their custody cases through the late 1970s, and that only fifteen percent of lesbian mothers won their cases in the early $1980 \mathrm{~s} .{ }^{45}$ However, this is because the national data obscure the important regional differences in lesbian mother custody determinations, which coincide with the liberal and conservative political leanings of each state. As the following tables demonstrate, lesbian mothers in Eastern and Western states were more likely to be successful in their custody petitions, with lesbian mothers in Eastern states winning eighty-six percent of their cases between 1979 and 1985, when studies on lesbian mothers emerged. After 1985, the number of cases in Eastern states dropped dramatically, likely because the shift in judicial norms made fathers less likely to challenge the rights of lesbian mothers. In Southern

45. "Homosexual, Civil Liberty Units Unite to Seek Rights," Daily Hampshire Gazette (Northampton, MA), July 18, 1978, Box 88, Folder 14, NGLTF; and E.R. Shipp, "A Lesbian Who Won Child Custody Battle," New York Times, September 5, 1981. 
states, by contrast, lesbian mothers consistently and overwhelmingly lost their petitions throughout the 1980s and 1990s. Midwestern states had a more mixed result, with lesbian mothers relatively successful prior to 1979, at which point their loss ratio increased substantially.

Table 3. Eastern States (All Sources) ${ }^{\mathrm{ii}}$

\begin{tabular}{lccrcrcr}
\hline Years & $\begin{array}{c}\text { Total } \\
\text { Cases }\end{array}$ & $\begin{array}{c}\text { Number } \\
\text { Won }\end{array}$ & $\begin{array}{c}\text { Percent } \\
\text { Won }\end{array}$ & $\begin{array}{c}\text { Number } \\
\text { Lost }\end{array}$ & $\begin{array}{c}\text { Percent } \\
\text { Lost }\end{array}$ & $\begin{array}{c}\text { Unknown } \\
\text { Result }\end{array}$ & $\begin{array}{c}\text { Percent } \\
\text { Unknown }\end{array}$ \\
\hline $1973-1978$ & 7 & 2 & $28.6 \%$ & 5 & $71.4 \%$ & 0 & $0.0 \%$ \\
$1979-1985$ & 14 & 12 & $85.7 \%$ & 1 & $7.1 \%$ & 1 & $7.1 \%$ \\
$1986-1992$ & 5 & 2 & $40.0 \%$ & 2 & $40.0 \%$ & 1 & $20.0 \%$ \\
$1993-1998$ & 2 & 2 & $100.0 \%$ & 0 & $0.0 \%$ & 0 & $0.0 \%$ \\
All & 28 & 18 & $64.3 \%$ & 8 & $28.6 \%$ & 2 & $7.1 \%$ \\
\hline
\end{tabular}

${ }^{\mathrm{ii}}$ Connecticut, Delaware, Massachusetts, Maine, Maryland, New Jersey, New York, Pennsylvania, Vermont.

Table 4. Southern States (All Sources) ${ }^{\text {iii }}$

\begin{tabular}{lccccccc}
\hline Years & $\begin{array}{c}\text { Total } \\
\text { Cases }\end{array}$ & $\begin{array}{c}\text { Number } \\
\text { Won }\end{array}$ & $\begin{array}{c}\text { Percent } \\
\text { Won }\end{array}$ & $\begin{array}{c}\text { Number } \\
\text { Lost }\end{array}$ & $\begin{array}{c}\text { Percent } \\
\text { Lost }\end{array}$ & $\begin{array}{c}\text { Unknown } \\
\text { Result }\end{array}$ & $\begin{array}{c}\text { Percent } \\
\text { Unknown }\end{array}$ \\
\hline $1973-1978$ & 7 & 2 & $28.6 \%$ & 5 & $71.4 \%$ & 0 & $0.0 \%$ \\
$1979-1985$ & 16 & 4 & $25.0 \%$ & 11 & $68.8 \%$ & 1 & $6.3 \%$ \\
$1986-1992$ & 15 & 4 & $26.7 \%$ & 10 & $66.7 \%$ & 1 & $6.7 \%$ \\
$1993-1998$ & 19 & 3 & $15.8 \%$ & 13 & $68.4 \%$ & 3 & $15.8 \%$ \\
All & 57 & 13 & $22.8 \%$ & 39 & $68.4 \%$ & 5 & $8.8 \%$ \\
\hline
\end{tabular}

iii Alabama, Arkansas, Florida, Georgia, Kansas, Kentucky, Louisiana, Missouri, North Carolina, Oklahoma, Tennessee, Texas, South Carolina, Virginia, West Virginia.

Table 5. Midwestern States (All Sources) ${ }^{\mathrm{iv}}$

\begin{tabular}{lccccccc}
\hline Years & $\begin{array}{c}\text { Total } \\
\text { Cases }\end{array}$ & $\begin{array}{c}\text { Number } \\
\text { Won }\end{array}$ & $\begin{array}{c}\text { Percent } \\
\text { Won }\end{array}$ & $\begin{array}{c}\text { Number } \\
\text { Lost }\end{array}$ & $\begin{array}{c}\text { Percent } \\
\text { Lost }\end{array}$ & $\begin{array}{c}\text { Unknown } \\
\text { Result }\end{array}$ & $\begin{array}{c}\text { Percent } \\
\text { Unknown }\end{array}$ \\
\hline $1973-1978$ & 12 & 9 & $75.0 \%$ & 3 & $25.0 \%$ & 0 & $0.0 \%$ \\
$1979-1985$ & 8 & 4 & $50.0 \%$ & 4 & $50.0 \%$ & 0 & $0.0 \%$ \\
$1986-1992$ & 6 & 1 & $16.7 \%$ & 4 & $66.7 \%$ & 1 & $16.7 \%$ \\
$1993-1998$ & 11 & 4 & $36.4 \%$ & 6 & $54.5 \%$ & 1 & $9.1 \%$ \\
All & 37 & 18 & $48.6 \%$ & 17 & $45.9 \%$ & 2 & $5.4 \%$ \\
\hline
\end{tabular}

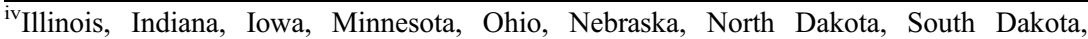
Wisconsin. 
Table 6. Western States (All Sources) ${ }^{\mathrm{v}}$

\begin{tabular}{lccrcccc}
\hline Years & $\begin{array}{c}\text { Total } \\
\text { Cases }\end{array}$ & $\begin{array}{c}\text { Number } \\
\text { Won }\end{array}$ & $\begin{array}{c}\text { Percent } \\
\text { Won }\end{array}$ & $\begin{array}{c}\text { Number } \\
\text { Lost }\end{array}$ & $\begin{array}{c}\text { Percent } \\
\text { Lost }\end{array}$ & $\begin{array}{c}\text { Unknown } \\
\text { Result }\end{array}$ & $\begin{array}{c}\text { Percent } \\
\text { Unknown }\end{array}$ \\
\hline $1973-1978$ & 21 & 9 & $42.9 \%$ & 8 & $38.1 \%$ & 4 & $19.0 \%$ \\
$1979-1985$ & 9 & 4 & $44.4 \%$ & 5 & $55.6 \%$ & 0 & $0.0 \%$ \\
$1986-1992$ & 2 & 1 & $50.0 \%$ & 1 & $50.0 \%$ & 0 & $0.0 \%$ \\
$1993-1998$ & 2 & 0 & $0.0 \%$ & 1 & $50.0 \%$ & 1 & $50.0 \%$ \\
All & 34 & 14 & $41.2 \%$ & 15 & $44.1 \%$ & 5 & $14.7 \%$ \\
\hline
\end{tabular}

${ }^{\mathrm{v}}$ Alaska, Arizona, California, Colorado, Nevada, Oregon, Utah, Washington, Wyoming.

These statistics demonstrate that only certain courts undertook normative shifts, and did so after liberal social science research emerged; this was especially true in the East. In courts resistant to lesbian mother custody demands, predominantly in the South and Midwest, other forms of authority, such as morality, were mentioned more frequently in their decisions. ${ }^{46}$ These courts expressed concerns about children's exposure to "immoral" behavior, as well as the problem of allowing "children to be placed in a home where the felony of sodomy is committed at least twice a week." 47 Given that only a small percentage of case records survived, the source base for these tables is limited in providing a quantitative account of change, but the data suggest trends that qualitative evidence also supports.

\section{Central Role of Expert Testimony in Custody Cases}

Expert testimony became central to custody cases when an increasing number of jurisdictions instituted a "nexus requirement" in the mid-1970s, which required evidence connecting the parent's homosexuality with harm to the children. This was a shift from a "per se" rule that homosexual parents were inherently unfit, which made it impossible for lesbian mothers or gay fathers to successfully petition for custody or visitation. The nexus

46. Julie Shapiro, "Custody and Conduct: How the Law Fails Lesbian and Gay Parents and Their Children," Indiana Law Journal 71 (1996): 658-60; and Richman, Courting Change, 26.

47. Lesbian Mothers National Defense Fund, Mom's Apple Pie, April 1975, Box 3000, Folder labeled "Visitation Rights," American Civil Liberties Union Records, Seeley G. Mudd Manuscript Library, Princeton University (hereafter ACLU); and Molly Moore and Tom Sherwood, "Homosexual Father Must Give Up Custody," Washington Post, January 19, 1985. 
requirement came about as a result of the fathers' rights movement, which challenged the presumption of maternal custody and demanded courts identify specific reasons for denying fathers equal custody rights. ${ }^{48}$ The nexus requirement rendered expert testimony essential for both sides; it placed the onus on the homosexual parent's ex-spouse to prove harm, thereby requiring ex-spouses to introduce expert psychological testimony to support their claims. At the same time, it forced lesbian mothers and gay fathers to present opposing experts, making expert testimony necessary for all parties. As Holly Lad, a member of the National Lawyers Guild, accurately predicted, requiring proof of harm to a child made it such that " "judges will have to rely much more heavily on the testimony of child psychiatrists in determining whether the child is suffering any detrimental effects." 49 Although the nexus requirement indicated that lesbian mothers and gay fathers were presumptively fit parents, many courts permitted speculation about potential future harm, as well as identification of wide-ranging and undefined harms, rendering the test meaningless. ${ }^{50}$ However, the nexus requirement did make it possible to introduce the social science evidence that would convince certain courts to grant homosexual parents custodial rights.

The requirement first appeared in the 1973 case of People v. Brown, in which a Michigan appellate court ruled that, although the probate court had heard evidence that Mae Brown and Arlene Smith were engaged in a lesbian relationship, this was insufficient to support the determination that the home was unfit for the children. The trial court's decision to deny the women custody had been based on their sexual orientation, even though the hearing testimony established that Brown had threatened Smith with a rifle and had tried to kill herself, Smith, and the children. ${ }^{51}$ Upon remand, the court allowed the children to return from foster care to their mothers' home. ${ }^{52}$ The nexus requirement quickly spread to other jurisdictions,

48. Dinner, "The Divorce Bargain," 113-14; and Shapiro, "Custody and Conduct," 633. 49. Jil Clark, "Major Court Decision Allows Lesbian Mother to Retain Custody," Gay Community News (Boston), February 3, 1979, Box 196, Folder 8, NGLTF.

50. Shapiro, "Custody and Conduct," 642.

51. People v. Brown, 212 N.W.2d 55, 58 (Mich. Ct. App. 1973).

52. Ibid., 57; Nan D. Hunter and Nancy D. Polikoff, "Custody Rights of Lesbian Mothers: Legal Theory and Litigation Strategy," Buffalo Law Review 2 (1975-76): 711-12; "Maine Lesbian Mother Wins Custody," Box 141, Folder 38, NGLTF; and Barbara Price, Draft of Lesbian Mother Case Summary, Box 3000, Folder Labeled "Custody Articles," ACLU, 25. The Brown children had originally been placed in foster care after being removed from Ms. Brown's home, but then were placed in the custody of their maternal grandparents. The court subsequently awarded custody to the father, and then transferred custody back to the grandparents. When the grandparents became ill and were no longer able to care for the children, the court restored custody to the mother. Upon discovering that Ms. Brown was 
largely because of the judicial shift from a presumption of maternal custody to the "best interests of the child" standard. The new standard required courts to conduct an intensive determination as to the preferable custodian, rejecting gender stereotypes in favor of fact-based adjudication. ${ }^{53}$ Because each trial turned on the facts of the case, experts needed to testify each time; judicial acceptance of an expert's opinion did not create a binding precedent for other families, although it could be persuasive authority.

Courts emphasized several possible types of problems that children reared by homosexual parents might have, often focusing on the possibility that children would be socially stigmatized or would grow up to be homosexual themselves. Although experts testified as to both issues, social science research focused on the future sexual orientation of the children, the question that came up most frequently and a topic to which scientists could provide special expertise through research studies. ${ }^{54}$ The idea that homosexuals actively recruited children to homosexuality was a pervasive notion that dated to the $1920 \mathrm{~s}$, and this concept had remarkable staying power despite shifts in scientific thought. As late as 1982, some ex-spouses and experts continued to allege that homosexual parents were "recruiting" the children through sexual abuse. ${ }^{55}$ Most of the custody and visitation cases, however, identified the threat of children becoming homosexual as being the result of living in a gay-friendly environment with gay role models. As Clifford Rosky has convincingly argued, conservative opponents of gay rights modernized the anti-gay rhetoric of the 1970s, moving away from seduction narratives to identifying indoctrination and role modeling as the threat gays and lesbians posed to children's sexual orientation. According to Rosky, "[b]y focusing on the impact of policies on children's sexual and gender development, opponents sought to bracket the legal and moral status of LGBT adults, while making more plausible empirical claims about the transmission of queerness." 56 This explains why, when the LMNDF sought nonprofit status in 1976, the IRS conditioned its tax exemption "on the understanding that none of your educational activities are designed to proselytize or influence any individual's sexual

once again living with her lesbian partner, the court returned the children to foster care. Brown, 212 N.W.2d at 57.

53. Martha Albertson Fineman, The Illusion of Equality: The Rhetoric and Reality of Divorce Reform (Chicago: University of Chicago Press, 1991), 85.

54. Richman, Courting Change, 29-30.

55. Karlis Streips, "Sexuality Is Crux of Visitation Dispute," Gay Life (Chicago), December 9, 1982, Box 88, Folder 17, NGLTF; and Pamela J. Laws, "Court Hears Final Arguments: Child Custody Case Pits Lesbian Against Husband, Former Lover," Metro Gay News (Detroit, MI), June 1977, Box 139, Folder 37, NGLTF.

56. Clifford J. Rosky, "Fear of the Queer Child," Buffalo Law Review 61 (2013): 638. 
orientation." ${ }^{57}$ Whereas earlier notions of recruitment turned on predatory behavior and child molestation, the ideas present in lesbian mother and gay father custody cases indicated a fear that homosexuality was taught by example. Although Daniel Rivers has argued that the visibility of the gay fathers movement "helped to refute the assertion that same-sex sexuality was pathological to children" by demonstrating that gay men were not antifamily, the conservative movement's shift toward emphasizing the dangers of gay role models rendered the profamily claims of gay fathers irrelevant to courts and the public more generally. ${ }^{58}$

Courts around the country were particularly concerned about a parent role modeling homosexuality when the child at issue was an adolescent. In 1974, California mother Carol Parrott lost custody of her daughters because the girls were nearing puberty. The trial judge emphasized that "the girls, who are $91 / 2$ and almost 11 years of age, are approaching a particularly sensitive period in their lives with respect to their emotional and physical development, and the mother's unconventional sexual relationship becomes of particular significance at this point in their lives." 59 The girls were placed in foster care in Kelso, Washington, a seventeen hour bus ride away from their mother. Because of Parrott's limited income from her job at Nichols Turkey Breeding Farm, she could at most afford the fifty-four dollar round-trip ticket to visit her daughters twice a year. ${ }^{60}$ Parrott had lost custody of her two other daughters in 1971, with the court placing the children in foster care because "[t]he carrying on of a relationship in the home which is presently viewed by society as much more abnormal, involving conduct presently considered illegal, and with no potential for legitimization, would represent the "threshold level of deficiency." 61 That the trial court considered a foster placement a better option for the children than a home with their lesbian mother is indicative of the extreme disapproval with which some courts approached homosexual relationships. This is particularly true given that, by the mid-1970s, the number of children in foster care was at an all-time high, leading Congress to focus on expediting the adoption of children "languishing in unstable foster arrangements" in $1980 .{ }^{62}$

57. Laine, Ottey, and Reinstein, Mom's Apple Pie.

58. Rivers, Radical Relations, 122.

59. Price, Draft of Lesbian Mother Case Summary, 28-29.

60. Appellant's Opening Brief, In re Deanna P. and Constance P., 1 Civil 34007-8 (Cal. App. Ct. Dec. 29, 1973), Folder 20, Box 124, Lyon/Martin Papers, 7-8.

61. Price, Draft of Lesbian Mother Case Summary, 26.

62. Dianne Creagh, "Science, Social Work, and Bureaucracy: Cautious Developments in Adoption and Foster Care, 1930-1969," in Children and Youth in Adoption, Orphanages, and Foster Care: A Historical Handbook and Guide, ed. Lori Askeland (Westport, CT: 
Before the emergence of the research studies, which identified sexual orientation as fixed in the first few years of a child's life, experts also expressed apprehension about the impact of parental homosexuality on adolescents, as in the 1974 case of Sandra Schuster and Madeleine Isaacson, which garnered nationwide publicity as one of the first lesbian mother victories before a state supreme court. Dr. S. Harvard Kaufman, a court-appointed Seattle psychiatrist, opined that, although there was no need to remove the children from their mothers' custody at this time, "the whole idea of a living situation may have to be reconsidered as the children go into adolescence." 63 Kaufman had told the court there was no danger prior to adolescence, and that the mothers' sexual orientation would only result in the children "grow[ing] up knowing more about homosexuality and human sexuality in general that most children," but that "this knowledge need not predispose them to become homosexuals." 64 The trial court ignored Kaufman's conclusion, despite claiming to have been "particularly impressed" by the psychiatrist, and ordered the women, who had met at their Pentecostal church and lived together with their six children, to separate their households. ${ }^{65}$ The women complied by moving into adjacent apartments, but the financial burden of running two homes led them to move back in together; the Washington Supreme Court later ruled that the women could continue to live together as samesex partners and raise their children together. ${ }^{66}$

Given judicial anxieties about the future sexual orientation of children raised in lesbian homes, social science evidence became crucial in custody contests. Throughout the 1970s and 1980s, courts in Eastern and Western states repeatedly cited expert testimony that a parent's homosexuality would not impact a child's sexual orientation as being a significant factor in their decisions to grant homosexual parents custody. ${ }^{67}$ In 1980, New

Greenwood Press, 2006), 34; and Adoption Assistance and Child Welfare Act, P.L. 96-272 (1980).

63. Letter from S. Harvard Kaufman to the Honorable James A. Noe, September 12, 1972, Custody of Children Subject File, ONE National Gay and Lesbian Archives (hereafter ONE).

64. Transcript of Court's Oral Decision, Schuster v. Schuster, No. 36868 (Wash. Super. Ct. King County, Sept. 3, 1974), Box 196, Folder 10, Lyon/Martin Papers, 5-6.

65. Ibid.

66. Nancy Faber, "Lesbians Madeleine Isaacson and Sandy Shuster Find 'Marriage' Happy but Hardly Untroubled," People, July 9, 1979; and Roger L. Winters, "Sandy \& Madeleine: 'We Won it All," Seattle Gay News, October 13, 1978, Box 125, Folder 5, Lyon/Martin Papers.

67. "Washington State Lesbian Mother Wins Custody," Box 88, Folder 14, NGLTF; "Mothers: A Dollar a Day Keeps the Husbands Away," Box 125, Folder 11, Lyon/Martin Papers; Linda Kohl, "Lesbian Granted Custody," St. Paul Pioneer Press, June 2, 1978, 
Jersey Superior Court Judge William J. D’Annunzio granted Rosemary Dempsey custody of her ten and eleven-year-old daughters, relying on psychiatrist Richard Green's testimony and research study about the future sexual orientation of children with homosexual parents. Dempsey, who was active in the lesbian-feminist movement, had lived with her partner, Margaret Wales, and Wales' three daughters for five years. This was the first case in which a New Jersey Court awarded custody to a lesbian mother living with her partner, and marked a sharp divergence from Bruce Voeller's 1974 case, in which the New Jersey court cited Voeller's involvement in the gay liberation movement as a reason to deny his custody petition. ${ }^{68}$ Likewise, the Massachusetts Appeals Court ruled in favor of a lesbian mother in 1983, citing the testimony of four unidentified psychologists. The opinion focused primarily on one expert, whose study comparing the children of heterosexual and homosexual parents revealed "“no difference in the minor children and no evidence of sexual dysfunction to a minor child reared by a single homosexual parent." 69

Expert testimony also benefited gay fathers, who used evidence that their homosexuality would not impact their children's future sexual orientation to win custody petitions. In 1982, the Oklahoma Supreme Court granted a gay father custody of his twin eleven-year-old sons, relying on psychiatric expert testimony about the children's sexual orientation. In a testament to the heterosexual imperative in custody cases, the father told the court "he 'has never encouraged the boys to adopt his own sexual preference and, indeed, prefers that they have the normal sexual orientation." 70 This father's statement indicates the way in which social science research, which emphasized that gay parents would not raise children with aberrant sexual orientations, reified heterosexuality. This case was one of the few in which a gay father engaged in a protracted custody dispute, as most gay

Box 88, Folder 19, NGLTF; National Gay Task Force, "NGTF Action Report," May 1979, Box 125, Folder 13, Lyon/Martin Papers; "Oklahoma Lesbian Mother Wins Custody (June 1979)," 1979, Box 88, Folder 19, NGLTF; Brent Whiting, "Phoenix Lesbian Wins Custody of Young Daughters from Court," Arizona Republic (Phoenix), April 14, 1980, Box 88, Folder 19, NGLTF; Hitchens and Thomas, Lesbian Mothers and their Children, 2; "Gay Wins Custody of Twin Sons," Advocate, November 1982, Box 88, Folder 8, NGLTF; and Philip S. Gutis, "Homosexual Parents Winning Some Custody Cases," New York Times, January 21, 1987.

68. Jil Clark, "Activist Lesbian Mother Wins N.J. Custody Battle," Gay Community News (Boston), August 16, 1980, Box 88 Folder 19, NGLTF; Larry Gordon, "Lesbians: Our House Is a Home; Mother Wins Custody, But Battle Is Far From Over," The Record (Bergen County, NJ), August 20, 1980, Box 71, Folder 50, NGLTF; and Shipp, "A Lesbian Who Won Child Custody Battle."

69. Gutis, "Homosexual Parents Winning Some Custody Cases."

70. "Gay Wins Custody of Twin Sons." 
fathers did not appeal court decisions denying them custody, leading many to become estranged from their children. ${ }^{71}$

Gay rights groups and movement lawyers recognized the key role of psychiatric testimony, repeatedly commenting on its crucial nature and disseminating information about experts and useful psychiatric studies to lesbian and gay parents. This continued the collaboration among gays, lesbians, and psychiatric researchers, which began prior to the 1973 declassification with Evelyn Hooker's studies and resulted in the APA's decision to declassify homosexuality from its Diagnostic and Statistical Manual of Mental Disorders (DSM). The National Gay Task Force (NGTF), one of the first organizations to take up the issue of homosexual parents, prepared a "Gay Parent Support Packet" that contained statements from ten nationally recognized experts, including Drs. Richard Green, Evelyn Hooker, John Money, Wardell Pomeroy, Judd Marmor, and Benjamin Spock. ${ }^{72}$ With the exception of Spock, who has been described as "arguably the most influential pediatrician of all time" and whose book, Baby and Child Care, was the world's second-best-selling book (after the Bible) for five decades, all of the letters came from psychiatrists and psychologists. ${ }^{73}$ The packet also provided statements of support from leading mental health organizations, and listed relevant psychiatric studies that concluded that a parent's homosexuality would not negatively impact his or her children. ${ }^{74}$ First published in 1973, the NGTF reissued the packet in 1979 to provide more up-to-date information for homosexual parents. The NGTF learned the importance of expert testimony from the experience of one of its leaders, Bruce Voeller, as the testimony of Dr. Richard Gardner, a child psychiatrist at Columbia University, was central to the court imposing strict limitations on visitation. ${ }^{75}$

The NGTF's information on psychiatric studies proved useful not only for litigants, but also for experts. In a 1980 case in Arizona, involving a lesbian couple who met in prison and sought to recover custody of their children after their release, the court required the attorney general's office to

71. Rivers, Radical Relations, 133.

72. National Gay Task Force, Gay Parent Support Packet, 1973, Box 105, Folder 7, NGLTF.

73. Ibid.; Jane E. Brody, "Final Advice from Dr. Spock: Eat Only All Your Vegetables," New York Times, June 20, 1998.

74. National Gay Task Force, Gay Parent Support Packet.

75. Stuart Lavietes, "Richard Gardner, 72, Dies; Cast Doubt on Abuse Claims," New York Times, June 9, 2003. Garner later became famous for developing the theory of parental alienation syndrome, which explained circumstances under which a child might falsely accuse a parent of abuse in contentious custody cases. Richard A. Gardner, "Misinformation Versus Facts About the Contributions of Richard A. Gardner, M.D.," American Journal of Family Therapy 30 (2002): 396-98. 
provide expert testimony on homosexual lifestyles. The state presented Dr. Dean B. Mitchell, a Phoenix psychologist who testified for $2 \frac{1}{2}$ hours as to whether lesbian women were competent parents, the stability of lesbian relationships, whether lesbians abused children, the likelihood that being raised by a lesbian couple would prevent a child from being heterosexual, and the pressures that the children would face from their peers. ${ }^{76}$ Mitchell, who worked with homosexual clients, based his testimony on his clinical experience and the information contained in the NGTF Gay Parent Support Packet. As he wrote to the NGTF, the combination of these two sources of information allowed him "to present a cogent presentation before the Juvenile Court." 77 The court awarded the mothers custody.

Much like the NGTF, other leading lesbian and gay rights litigation groups emphasized the importance of psychological studies and expert testimony. Marilyn Haft, who founded the American Civil Liberties Union's (ACLU) Sexual Privacy Project in 1973, always introduced expert testimony in the cases she litigated, not only to benefit the men and women she represented, but also to create a record on which other homosexual parents could rely. She distributed copies of the experts' testimony to other lawyers and gay rights activists around the country to use in custody cases. ${ }^{78}$ Likewise, the LMNDF provided information to attorneys who contacted the organization, creating a litigation manual for lesbian mothers and identifying experts whom the mothers could retain. However, the costs of hiring experts were substantial; in highly contested cases, lesbian mothers might spend thousands of dollars on experts, and tens of thousands of dollars on lawyer and court fees. ${ }^{79}$ The Lesbian Rights Project, a program founded by Donna Hitchens under the auspices of the women's rights group Equal Rights Advocates, also published resources that underscored the crucial role of mental health theories to custody litigation. ${ }^{80}$ One of their first publications included a handbook entitled Lesbian Mothers and their Children: An Annotated Bibliography of Legal and

76. "Lesbians Win Custody in AZ Court," Sunday's Childe (Phoenix, AZ), April 1980, Box 88, Folder 19, NGLTF; and Whiting, "Phoenix Lesbian Wins Custody."

77. Letter from Dean B. Mitchell to National Gay Task Force, April 23, 1980, Box 88, Folder 19, NGLTF.

78. Marilyn Haft, interview by author, June 26, 2014.

79. Friends of Mary Jo Risher, Mailing, n.d., ca. 1975, Box 125, Folder 2, Lyon/Martin Papers; Lesbian Mother Fights Back, n.d., ca. 1978, Box 124, Folder 14, Lyon/Martin Papers; and Lesbian Mothers' National Defense Fund, "Custody Decision a Disaster," Mom's Apple Pie, 1993, Box 105, Folder 14, Lyon/Martin Papers.

80. The Lesbian Rights Project became independent in 1988 and changed its name to the National Center for Lesbian Rights. National Center for Lesbian Rights, Founders Bio, http://www.nclrights.org/about-us/mission-history/founders-bio/ (September 1, 2014). 
Psychological Materials in $1980 .{ }^{81}$ This was soon followed by the Lesbian Mother Litigation Manual, published in 1982, which devoted an entire chapter to expert testimony, and highlighted the importance of psychiatric studies in its sample trial brief and evidentiary motions. ${ }^{82}$ Other organization leaders reinforced the central role of mental health theories when giving press interviews. Nan Hunter, Director of the ACLU Lesbian and Gay Rights Project, told the Atlanta Journal-Constitution that the legal position of lesbian and gay parents was improving "because there has now developed a body of psychological and other scientific literature that shows conclusively that the homosexuality of a parent has no harmful impact on the child." 83 Barbara Levy, Executive Director of Lambda Legal Defense \& Education Fund, similarly emphasized to the gay press the importance of educating judges as to the fitness of lesbian and gay parents in successfully litigating custody cases. ${ }^{84}$

Gay rights lawyers and advocates stressed the need for custody litigants to introduce expert testimony and research studies, demonstrating the extent to which this material had become crucial to custody cases as courts increasingly instituted the nexus requirement. Forced to show a tangible harm that the children would suffer as a result of parental homosexuality, heterosexual ex-spouses often claimed that children raised by lesbian mothers or gay fathers would grow up to be homosexual themselves. To counter this claim, scientists focused their research on the future sexual orientation of children, creating a body of expert material that would help lesbian mothers and gay fathers in their custody suits.

\section{Pro-Gay and Lesbian Parenting Studies}

The researchers who undertook studies in the late 1970s and early 1980 s to address judicial concerns about the effect of parental homosexuality on children uniformly demonstrated that children raised by gay and lesbian parents were not more likely to become homosexual than children raised by heterosexual parents. ${ }^{85}$ Although courts raised a number of other

81. Hitchens and Thomas, Lesbian Mothers and Their Children.

82. Donna J. Hitchens, Lesbian Mother Litigation Manual (San Francisco: Lesbian Rights Project, 1982), Box 124, Folder 3, Lyon/Martin Papers.

83. Maureen Downey, "Custody Battle Illuminates Courts' Bias: Lesbian Mom Loses Her Son and Her Job," Atlanta Journal Constitution, May 21, 1987.

84. Michigan Supreme Court Awards Custody to Lesbian Mother, 1979, Box 88, Folder 14 , NGLTF.

85. These studies did not address the cause of sexual orientation, although they implied that sexual orientation was immutable, an issue that would become relevant in later equal 
psychological questions, including the possibility that children would suffer from social stigma, researchers focused their studies on the sexual orientation of children raised by gay and lesbian parents, the question on which judicial fears centered. Until these research studies emerged, many in the mental health professions assumed that parental sexual orientation shaped children's psychosexual development, and, therefore, that homosexual parents were more likely to raise homosexual children. These studies thus challenged psychological conventions and changed the way in which practitioners understood lesbian mothers and gay fathers. The impact of the studies on mental health professionals was particularly important, as most custody cases involved local psychiatrists, psychologists, and social workers, whom lawyers selected as their experts because they were known to and respected by the family court judges. ${ }^{86}$ Most of the researchers were already interested in issues of gender and sexuality before undertaking the studies, but decided to focus on how parental homosexuality influenced children's sexual orientation specifically because of lesbian mother custody cases. Although these scientists were sympathetic to gay rights claims, they did not see themselves as activists, but rather identified as scientists conducting research that implicated a social movement.

Richard Green was the first scientist to undertake research on the impact of parents' homosexuality on their children. Green had focused his career on the study of sexuality and gender identity, prompted by his teenage fascination with Christine Jorgensen. ${ }^{87}$ Upon entering medical school, Green immediately began working with John Money, a scientist renowned for his work on intersex conditions and gender identity. ${ }^{88}$ Together, they conducted research that focused on the need for parents to model traditional gender roles to avoid "gender role anomalies," which they concluded were ingrained "very early in life." 89 After graduating, Green studied psychoanalysis under Robert Stoller, a leader in gender identity research and a professor at UCLA's Gender Identity Research Clinic, and founded the Archives of Sexual Behavior and the International Academy of Sex Research. Green was one of the first psychiatrists to publish an article in

protection arguments for gay rights. Nancy J. Knauer, "Science, Identity, and the Construction of the Gay Political Narrative," Law and Sexuality 12 (2003): 74-78.

86. Nan Hunter, interview by author, March 18, 2014.

87. Joanne Meyerowitz, How Sex Changed: A History of Transsexuality in the United States (Cambridge, MA: Harvard University Press, 2002), ch. 2.

88. Suzanne J. Kessler, Lessons from the Intersexed (New Brunswick, NJ: Rutgers University Press, 1990), 14.

89. Richard Green and John Money, "Incongruous Gender Role: Nongenital Manifestations in Prepubertal Boys," Journal of Nervous and Mental Disease 131 (1960): $166-67$. 
a peer-reviewed journal arguing for the declassification of homosexuality from the DSM, and was active in the 1973 declassification debates..$^{90}$

Green first testified in a lesbian mother custody case in 1974, when he concluded in Hall v. Hall that the mother's lesbianism would not impact the sexual orientation of her daughter because the child conformed to traditional gender roles. Green stressed that, in recounting role-playing games, the daughter played "the mommy and [the other child] plays the daddy. Her favorite toys are Barbie dolls, and the wedding gown which she wears." 91 Green also made it clear that the mother and her partner encouraged the child to develop along gender normative lines, testifying that they primarily provided the girl with dresses and feminine toys such as Barbie dolls. ${ }^{92} \mathrm{He}$ predicted that the girl "will be a female feminine heterosexual lady." 93

Green's methodology, which tied gender roles and sexual orientation, satisfied both of the major psychological explanations for homosexuality at the time, one of which was rooted in psychoanalysis and the other in social learning theory. Despite their different theoretical origins, both emphasized the importance of early-age gender role development in determining sexual orientation. Psychoanalysts conceptualized sexual orientation as resulting from the resolution of the Oedipus and Electra complexes, whereas social learning theory understood gender identity as being based on "a perceived similarity between the child and the ... parental role model." "94 Both linked "inappropriate" or "atypical" gender role behavior in childhood with homosexuality in adulthood, with social learning theorists describing preadolescent boys who exhibited "atypical gender-role behavior" as "prehomosexual" and recommending psychiatric treatment. ${ }^{95}$ According to these theories, the gender roles that children exhibited indicated what their adult sexual orientation would be, and therefore gender conformity served as a proxy for future heterosexuality. ${ }^{96}$ Because Green believed that gender roles and sexual orientation were fixed early in life, he did not believe

90. Richard Green, interview by author, May 31, 2014; and Ronald Bayer, Homosexuality and American Psychiatry: The Politics of Diagnosis, rev. ed. (1981; repr., Princeton: Princeton University Press, 1987), 112.

91. Transcript of Examination of Richard Green, Hall v. Hall, No. 55900 (Ohio C.P. Licking County, Apr. 26, 1974), Box 124, Folder 10, Lyon/Martin Papers, 27.

92. Ibid., 25-26.

93. Ibid., 27.

94. Diane Richardson, "Theoretical Perspectives on Homosexuality," in The Theory and Practice of Homosexuality, ed. John Hart and Diane Richardson (London: Routledge, 1981), 23.

95. Ibid., 24.

96. The pro-gay and lesbian parenting research pointed to early childhood as the time when sexual orientation became fixed, although adolescence continued to be an important, albeit less critical, phase. M.J.P v. J.G.P., 640 P.2d 966, 968-69 (Okla. 1982). 
that lesbian motherhood would have any effect on children after the first two to three years of their lives. ${ }^{97}$

Green's method of predicting sexual orientation based on conformity to gender roles also guided his landmark study on the sexual orientation of children raised by lesbian mothers, which he published in 1978. Over a period of two years, he studied thirty-seven children between the ages of three and twenty raised by lesbians or transsexuals; he found that that thirty-six of them "have conventional sexual preferences or are on their way to developing them." All thirteen of the children who had reached adolescence were sexually attracted to members of the opposite sex. Green measured the sexual identity of the younger children by analyzing their toy, game, and clothing preferences; composition of friend groups; drawings; and career aspirations. Most of the girls favored playing with dolls and wanted to become nurses, whereas the boys generally identified cars as their favorite toys and selected the male-dominated professions of firefighters, police officers, and doctors. A third of the preadolescent children transgressed gender norms in identifying their ideal professions, including three girls who wanted to be doctors or scientists, and three boys who aspired to be artists and nurses, but Green nevertheless concluded that they had developed conventional gender identities. Green suggested that a parent's sexuality had little effect on that of their child, as children "are exposed through mass media and their peers to conventional family styles and conventional patterns of psychosexual development." 98 Green would later publish a book-length study of the factors influencing children's sexual identity and sexual orientation. ${ }^{99}$

Although Green's research had always focused on sexual orientation and gender roles, he undertook a study of lesbian mothers and their children because of the questions that courts had raised; Green was concerned that lawyers and other psychiatrists were using children's future sexual orientation as an argument against homosexual parents. ${ }^{100}$ In his study, he

97. Richard Green, Sexual Science and the Law (Cambridge, MA: Harvard University Press, 1992), 28. In the seventeen lesbian mother and two gay father custody cases that involved children three years old or younger, custody rulings involved a mix of wins and losses. In the case of the youngest child, who was seventeen months old, the court ruled against the lesbian mother because of her "moral unfitness." White v. Thompson, 569 So.2d 1181, 1184 (Miss. 1990).

98. Richard Green, "Sexual Identity of 37 Children Raised by Homosexual or Transsexual Parents," American Journal of Psychiatry 135, no. 6 (1978): 695-96; and "Children of Homosexuals Seen Headed Straight," Psychology Today, November 1978, Box 71, Folder 50, NGLTF.

99. Richard Green, The "Sissy Boy Syndrome" and the Development of Homosexuality (New Haven: Yale University Press, 1987).

100. Green, interview by author. 
plainly asserted that he "hope[d] that this report may be of value" for "courts [that] are being forced to deal with this issue." 101 Green chose to structure his 1978 study using predictors of future sexual orientation, rather than undertake a longitudinal project, "because of the lesbian mother [custody] trials," which required immediate results. A study that tracked children over time would have come too late to help lesbian mothers who were seeking custody in the 1970s and 1980s. Green also hoped that his work would help other mental health professionals testifying in lesbian mother cases, who could cite his study as evidence about the future sexual orientation of children raised by homosexual parents. ${ }^{102}$ Green had been aware of and concerned about lesbian mother and gay father cases for several years before undertaking the study, and had worked to improve the legal landscape for these parents. In an interview with historian Daniel Rivers, Green acknowledged that, for him, "the struggle to remove homosexuality from the APA's list of mental disorders was directly linked to the assertion that having lesbian or gay parents was not necessarily contrary to the "best interests of the child."'103

After publishing the results of his first study in 1978, Green then undertook a second, controlled research study that compared the children of lesbian and heterosexual mothers. Similarly framing his research in terms of addressing judicial concerns and the "best interests of the child," Green's second study also did not identify any difference in sexual identity between the two groups of children. ${ }^{104}$ This research applied similar testing procedures as his earlier work, analyzing toy and game preferences, drawings, and peer groups. Although the final conclusions of the study were not available until 1986, two of the postdoctoral psychiatrists who worked with Green published preliminary results in 1982. The introduction to their article emphasized the growing number of lesbian mother custody cases, and identified its purpose as "review[ing] literature pertinent to the issues of child custody concerns and to report in greater depth on research projects involving lesbian mothers and their prepubescent children." Before discussing the results, the psychiatrists explained that "[t]he study was designed to test several of the specific issues brought up in lesbian mother custody cases." The researchers concluded their article by stating "[o]ur research and that of others does not support the usual concerns raised in family courts, which typically regard the homosexual as an

101. Green, "Sexual Identity of 37 Children," 696.

102. Green, interview by author.

103. Rivers, Radical Relations, 69.

104. Richard Green, Jane Barclay Mandel, Mary E. Hotvedt, James Gray, and Laurel Smith, "Lesbian Mothers and Their Children: A Comparison with Solo Parent Heterosexual Mothers and Their Children," Archives of Sexual Behavior 15 (1986): 180. 
unfit parent" and emphasizing that the study revealed no evidence of gender identity conflict among the children of lesbian mothers. ${ }^{105}$

Lesbian mother custody cases inspired other researchers, and the immediacy of the legal battles led these scientists to undertake short-term studies that predicted sexual orientation. ${ }^{106}$ Psychiatrist Martha Kirkpatrick and her colleagues at the University of California at Los Angeles (UCLA) published their study of forty children between the ages of five and twelve in 1980, half raised by heterosexual women and the other half by lesbians. Like Green, Kirkpatrick's team cited lesbian custody cases as a primary motivator for undertaking their research. ${ }^{107}$ Kirkpatrick and her associates had all participated in Stoller's Saturday morning seminars at UCLA, diagnosing gender dysphoria and prescribing treatments. Because the patients were almost exclusively male, Kirkpatrick wanted to expand her work by studying women, and decided to undertake a study of lesbian mothers and their children after hearing press accounts of lesbian mother custody battles. Because "courts didn't know what to do about [these types of cases]," Kirkpatrick hoped a study would "make it possible to make a better judgment about how these cases should be handled." 108

Kirkpatrick's work "found no evidence of developmental difficulties, gender disorders or increased likelihood of homosexuality in these children."109 As in Green's study, Kirkpatrick's team drew its conclusions based on the children's favorite toys, characters they chose when engaging in imaginative play, sex of their friends, drawings, and responses to interview questions about "sex, current interests, and future roles in life." 110 In discussing specific participants, the Kirkpatrick study highlighted gender conformity and the lesbian mothers' emphasis on raising heterosexual children: "Mother states she hopes Sara is heterosexual in adult life. Sara enjoys dressing up as a princess in mother's high heels and negligee and plays the Mommie in imaginary games." 111 Relying on social learning theory, the researchers concluded that Sara's "good relationship with her

105. Mary E. Hotvedt and Jane Barclay Mandel, "Children of Lesbian Mothers," in Homosexuality: Social, Psychological, and Biological Issues, ed. William Paul, James D. Weinrich, John C. Gonsiorek, and Mary E. Hotvedt (Beverly Hills, CA: SAGE Publications, 1982), 276, 281, 285.

106. Julie Schwartz Gottman, "Children of Gay and Lesbian Parents," in Homosexuality and Family Relations, ed. Frederick W. Bozett and Marvin B. Sussman (New York: Harrington Park Press, 1990), 180.

107. Martha Kirkpatrick, Catherine Smith, and Ron Roy, "Lesbian Mothers and Their Children: A Comparative Study," American Journal of Orthopsychiatry 51 (1981): 545.

108. Martha Kirkpatrick, interview by author, June 16, 2014.

109. Gutis, "Homosexual Parents Winning Some Custody Cases."

110. Kirkpatrick, Smith, and Roy, "Lesbian Mothers and Their Children," 549.

111. Ibid. 
mother appeared to make possible the gender-appropriate use of the male figures available." 112 These male influences would ensure that Sara would become heterosexual.

Whereas Kirkpatrick and Green were both psychiatrists, researchers in other disciplines also conducted studies on the impact of parental homosexuality on children's future sexual orientation, all also pointing to judicial questions as the impetus for their research. Although psychiatrists at this time were fighting to maintain their authority over psychologists, social workers, and other mental health professionals, the dearth of research on this subject rendered any studies useful and bridged the barriers between the professions. ${ }^{13}$ In 1981, the same year that Kirkpatrick published her research, Beverly Hoeffer, a Registered Nurse and Doctor of Nursing Science, published a similar study. Like Kirkpatrick's team, Hoeffer compared the toy and activity preferences of the children of lesbian and heterosexual mothers to analyze the mothers' influence on children's gender roles and sexual identity, finding no difference. Hoeffer explained her study's focus by citing child custody litigation. ${ }^{114}$ The next year, Ellen Lewin, an anthropologist at the University of California at Berkeley, published her comparison of eighty divorced lesbian and heterosexual mothers, concluding that both reflected "fairly traditional notions about family" and sought to provide male role models for their children, typically the children's fathers. ${ }^{15}$ Lewin also cited "the questions that the judicial system has raised" in lesbian custody cases to explain her research agenda, entitling her preliminary report "Lesbianism and Motherhood: Implications for Child Custody."116 Lewin began her research in 1977, after hearing about Mary Jo Risher and Jeanette Jullion's custody battles, with the "fantasy that [she] would be called upon to be an expert witness in some of these cases." 117 Working with Terrie Lyons, a licensed social worker and doctoral candidate, the pair presented their initial research findings at the annual meeting of the American Psychological Association in 1979. ${ }^{118}$ Lewin's study did not

\section{Ibid.}

113. Rick Mayes and Allan V. Horwitz, "DSM-III and the Revolution in the Classification of Mental Illness," Journal of the History of the Behavioral Sciences 4 (2005): 256-57, 265.

114. Beverly Hoeffer, "Children's Acquisition of Sex-Role Behavior in Lesbian-Mother Families," American Journal of Orthopsychiatry 51 (1981): 536-37.

115. Ellen Lewin, "Lesbianism and Motherhood: Implications for Child Custody," Human Organization 40 (1981): 6-14.

116. Ibid., 6.

117. Ellen Lewin, interview by author, September 19, 2014; and Ellen Lewin, email message to Joanne Meyerowitz, August 19, 2014, author's possession.

118. Martha J. Kirkpatrick, "Lesbian Mothers and their Children," 1999, unpublished manuscript, author's possession, 29; and Terrie A. Lyons, "Lesbian Mothers' Custody Fears," Women \& Therapy 2 (1983): 232. 
directly examine the sexual orientation of children raised by lesbians, but did indicate that these children were raised with heterosexual male role models. Lewin's different focus indicates that the questions researchers were asking were expanding beyond the initial question of future sexual orientation. Also in 1982, social workers at the University of Southern California (USC) conducted a study of children between the ages of seven and twelve being raised by a lesbian mother and her female partner, finding that the children were well adjusted. The study also looked at gender roles, emphasizing that the boys did not identify with female role models, and concluding, like Green, that "“[b]oys are exposed to men outside the family and through television and movies and a wide range of other sources." 119 Jessica Lehman, one of the USC researchers, emphasized the need for research into lesbian mothers, as "[1]egal precedents [were] being set with virtually no empirical basis." 120

Lesbian custody cases also spurred scientific research outside of the United States, producing studies that American lesbian mothers would rely upon in court. Susan Golombok, a leading researcher in the United Kingdom, began her career with a study of lesbian mothers after reading an article about lesbian custody disputes in the feminist magazine Spare $R i b$. The article detailed the difficulties that lesbian mothers faced in court, and stressed the need for social science research to support lesbian mothers' custody claims. ${ }^{121}$ Golombok contacted Action for Lesbian Parents, the advocacy group mentioned in the article, which put Golombok in contact with lesbian mothers and their children. Golombok conducted the initial study as her master's thesis; when renown child psychiatrist Michael Rutter learned of Golombok's work, he offered to find funding so that she could expand her research as a doctoral dissertation project. Rutter had testified as an expert witness in a number of lesbian mother custody cases and recognized the need for social science research to support lesbian mother claims. ${ }^{122}$ Golombok published her findings in 1983, which concluded there were no differences in the gender identity, sex role behavior, or sexual orientation of children raised in lesbian and heterosexual single mother households. ${ }^{123}$ This study provided additional

119. "Study Finds Advantages to Custody Awards to Lesbians," Los Angeles Daily Journal, March 21, 1981, Box 88, Folder 19, NGLTF.

120. Ibid.

121. "Out of the Closet Into the Courts: Eleanor Stevens Reports on Discrimination Against Lesbian Mothers in Custody Battles," Spare Rib, September 1976, 6-8.

122. Susan Golombok, interview by author, August 28, 2014.

123. Susan Golombok, Ann Spencer, and Michael Rutter, "Children in Lesbian and Single-Parent Households: Psychosexual and Psychiatric Appraisal," Journal of Child Psychology and Psychiatry 24 (1983): 568. 
support for lesbian mothers and their advocates, who drew upon Golombok's work in asserting custody rights. ${ }^{124}$

Whereas most of the research in the late 1970s and early 1980s focused on lesbian mothers, the primary litigants in homosexual parent cases, sociologist Brian Miller of the University of Alberta published a study of gay fathers and their children in 1979. His research openly addressed custody cases, analyzing the impact of custody trials on the children of gay men. ${ }^{125}$ Miller's study indicated that "“[s]econd generation homosexuals are rare,"” and that neither gay fathers nor their homosexual friends molested children. Miller concluded that the father-child relationships he studied improved after the parents' divorce, as the fathers left unhappy marriages and began to live openly gay lives. Miller's study remained the sole investigation of gay fathers for almost a decade; Frederick Bozett's subsequent work in the late 1980s supported Miller's research and extended its conclusions, arguing that "gay parents are as effective and may be even more so in some ways than nongay parents." 126 Bozett also noted that courts and social welfare agencies were primarily concerned with the future sexual orientation of children with gay fathers, but derided this objection as "mask[ing] a deeper, more homophobic and hostile reaction about this type of alternative family rather than reflecting true concern for children." 127 Bozett's willingness to dismiss the question of children's future sexual orientation indicates the extent to which liberal researchers had accepted the "no difference" conclusion and were turning to other questions about gay and lesbian parenting.

All of these researchers explicitly recognized the importance of their work for custody cases, and a number of gay and lesbian parents successfully employed these studies in their custody disputes. However, their limited scope made some courts hesitant to rely upon them. In the 1980 case of Hulett v. Hulett, the Kansas court denied a lesbian mother custody after determining that the scientific evidence she had presented was inconclusive because of the studies' "preliminary nature." The court focused on the lack

124. Brief of Appellant, Teegarden v. Teegarden, No. 38A04-0406-CV-212, 1994 WL 16461688, at *16 n.4 (Ind. App. Ct. July 5, 1994); Brief of Appellee, Bottoms v. Bottoms, No. 94-1166, 1994 WL 16199380, at*16 n.6 (Va. Dec. 28, 1994); and In re Adoption of Evan, 583 N.Y.S.2d 997, 1001 n.1 (Sur. Ct. 1992).

125. Marilyn Elias, "Are Gays Fit Parents?," San Francisco Chronicle, September 3, 1979, Box 141, Folder 38, NGLTF.

126. Jerry J. Bigner and Frederick W. Bozett, "Parenting by Gay Fathers," in Homosexuality and Family Relations, 163; and Frederick W. Bozett, "Children of Gay Fathers," in Gay and Lesbian Parents, ed. Frederick W. Bozett (New York: Praeger, 1987), 39.

127. Bigner and Bozett, "Parenting by Gay Fathers," 165. 
of longitudinal studies, a problem that child development specialists readily conceded. Kirkpatrick herself stated that the lack of long-term research limited the conclusions that could be drawn from studies of homosexuals and their children. ${ }^{128}$ Lesbian rights activist Rosalie Davies, who went to law school after fighting her own custody case, criticized the research studies on the same basis, maintaining that "the samples were too small and the children had not been observed over a long enough period of time for the studies to withstand a strong challenge by antihomosexual groups."129 Many courts nevertheless accepted these research studies, granting homosexual parents custody based on their conclusions. ${ }^{130}$ In Blew v. Varta, for example, a Pennsylvania appellate court relied on the Green and Kirkpatrick studies to grant Beth Blew and her partner partial custody of eight-year-old Nicholas. The court explained "that a variety of psychological studies indicate that lesbianism does not correlate negatively with the ability to raise a healthy, normal child." 131 Likewise, in the 1987 case of Conkel v. Conkel, the Ohio Court of Appeals relied upon Green's work in granting a gay father overnight visitation with his seven- and ten-year-old boys. ${ }^{132}$ Green's work, the court found, undermined the mother's claim that the father's sexual orientation would impact that of his children. Although Conkel was an Ohio case, courts relying on research studies were primarily in Eastern and Western states, where judges were more open to considering lesbian mother and gay father custody claims in the first instance; these courts could then stave off criticism by rooting their decisions in the emerging social science research. ${ }^{133}$

Although these pro-gay parenting studies, which emphasized the benign impact of a parent's homosexuality on children, were crucial for lesbian and gay men to obtain custody, they tacitly promoted the idea that homosexuality was undesirable. By emphasizing that children raised in gay and lesbian households were not more likely to grow up to be homosexual, researchers "implicitly accept[ed] a view of homosexuality as a negative outcome of development."134 As one of sociologist Diane Richardson's interviewees perceptively noted, "in order to keep my children I've had

128. Gutis, "Homosexual Parents Winning Some Custody Cases."

129. Shipp, "A Lesbian Who Won Child Custody Battle"; and Jodi-Ellen Dash, "Lesbian Mothers: Child Custody is More a Matter of Luck than Law," Bucks County Courier Times (PA), 1977, Custody of Children Subject File, ONE.

130. Gutis, "Homosexual Parents Winning Some Custody Cases."

131. Blew v. Varta, 617 A.2d 31, 36 n.2 (Pa. Super. Ct. 1992).

132. Conkel v. Conkel, 509 N.E.2d 983, 986-87 (Ohio Ct. App. 1987).

133. Gutis, "Homosexual Parents Winning Some Custody Cases."

134. Diane Richardson, "Lesbian Mothers," in The Theory and Practice of Homosexuality, 156. 
to agree to bring them up to be heterosexual, whatever that means, and I ask myself what does that say about being gay, which I am." 135 Marc Stein has explained that litigants and lawyers are often constrained by a legal system that "encourages cautious and conservative argumentation," such that success depends upon convincing courts that their decisions are "compatible with the tenets of heteronormative supremacy."136 Researchers crafting studies that gay and lesbian litigants could use to bolster their custody suits by necessity also adopted a heteronormative approach, helping to perpetuate the view of homosexuality as an aberration that needed to be avoided. ${ }^{137}$

\section{Conservative Response}

Whereas pro-gay and lesbian parenting studies proved useful for litigants in Eastern and Western states, and helped shift legal norms in those regions, this was not true in conservative states, where Christian ideology dominated politics. In the late 1980s and 1990s, when lesbian mothers and gay fathers in the South and Midwest began asserting their rights more frequently, judges often based their denials on the possibility that the children would become homosexual. By this time, conservative researchers had begun conducting their own studies of gay and lesbian parents, concluding that homosexual parents were more likely to raise gay children. The rise of conservative scientific research was part of a larger resurgence of the political right in the 1980s, which waged a "cultural war" that included anti-homosexuality as a central tenet and gained currency as the AIDS epidemic unfolded. ${ }^{138}$ As Didi Herman has documented, leading Christian Right organizations relied heavily on scientific evidence

135. Ibid.

136. Stein, Sexual Injustice, 97.

137. Researchers like Lewin and Bozett, whose studies focused on family structures rather than future sexual orientation, did not adopt this position. However, because their work did not address the concerns of judges, it had less impact on custody and visitation cases.

138. Self, All in the Family, 383-95, 401-04; Laura Kalman, Right Star Rising: A New Politics, 1974-1980 (New York: W.W. Norton, 2010), 263-64, 273-741; Darren Dochuk, From Bible Belt to Sun Belt: Plain-Folk Religion, Grassroots Politics, and the Rise of Evangelical Conservatism (New York: W.W. Norton, 2011), 383-84, 393; Sean Wilentz, The Age of Reagan: A History, 1974-2008 (New York: HarperCollins, 2008), 185-86; and Steven Seidman, "Transfiguring Sexual Identity: AIDS \& the Contemporary Construction of Homosexuality," Social Text 19 (1988): 189, 193-94. 
that homosexuality was a behavioral choice, using this work to argue that gays and lesbians were undeserving of legal protections. ${ }^{139}$

However, the court opinions denying lesbian and gay parents custody and visitation did not cite the conservative scientific research. The primary source of authority remained morality and common sense; courts ignored the scientific studies, even though they supported conservative positions, indicating they were unnecessary to justify the decisions. In the absence of changing judicial norms, social science research did not serve a vital function in explaining custody determinations. In Black v. Black, a 1988 case in Tennessee, the appellate court stated: "We feel it is unacceptable to subject children to any course of conduct that might influence them to develop homosexual traits, and the facts of this case indicate that there is a strong possibility, because of the living arrangements of Mother and her lover, the children would be subjected to such influences." 140 The court did not cite any studies or expert testimony in support of this statement. Similarly, when Jon Johnson moved to restrict the visitation rights of his lesbian ex-wife, Dianne Schlotman, because "he wouldn't allow Dianne to turn the children into homosexuals "by example and practice," the North Dakota trial court concurred. In 1991, the court rescinded Schlotman's visitation; by that point, her son Travis had come to believe "there is something wrong with him because his mother is a lesbian," and daughter Holly asserted that "she hates her mother because she is a lesbian and said she doesn't want to see her again." 141 The North Dakota Supreme Court upheld the lower court ruling two years later. More notoriously, a Florida trial court in 1996 removed an eleven-year-old girl from her lesbian mother's custody because it feared the child would "be led into [a lesbian] lifestyle ... by virtue of the fact of her living accommodations." 142 The judge placed the girl, who had lived with her mother all of her life, with her father, who had been convicted of murdering his first wife and had been accused of abusing another of his daughters. These cases appear to have been decided based on the assumptions of the judges, rather than scientific evidence.

The fear that a child would grow up to be homosexual was compounded when the homosexual parent was in a relationship, particularly if he or she

139. Didi Herman, The Antigay Agenda: Orthodox Vision and the Christian Right (Chicago: University of Chicago Press, 1997), 69-72.

140. Black v. Black, 1988 WL 22823, at *3 (Tenn. Ct. App. Mar. 10, 1988).

141. Lesbian Mothers' National Defense Fund, "Custody Decision a Disaster."

142. Transcript of Ruling on Motions, Ward v. Ward, No. 92-2424-CA01-H (Fla. Cir. Ct. Escambia County Aug. 23, 1995), Box 1, Folder Labeled "Custody/Ward Court Case, 1995," Records of Children of Lesbians and Gays Everywhere (COLAGE), Collection Number 2001-04, GLBT Historical Society, 83; and Beatrice Dohrn, "Custody Paradox," Lambda Update, Fall 1996, Box 105, Folder 14, Lyon/Martin Papers. 
lived with a same-sex partner. In a number of cases, heterosexual fathers who had been aware of their ex-wives' lesbianism only filed suit for custody after learning that their ex-wives had entered into serious relationships or were living with their partners. ${ }^{143}$ Some courts denied homosexual parents in romantic relationships custody or visitation, but more often judges imposed restrictions on the relationships. ${ }^{144}$ These limits ranged from prohibiting lesbian mothers and gay fathers from showing any physical affection to their partners while the children were in the home, to conditioning custody and visitation on the partner moving out. ${ }^{145}$ In the 1996 case of Pamela Hertzler, a Wyoming court took a particularly virulent stand towards a lesbian mother who allowed her children to "snuggle" in bed with her partner and participate in the couple's commitment ceremony, finding that "the children had been 'eroticized' during their visits with Pamela." 146 The court restricted visitation to six weekends per year, with no overnight visitation; it also forbade any contact between Pamela's partner and the children. The Wyoming Supreme Court, despite deriding the homophobic language of the trial court opinion, upheld the limitations. ${ }^{147}$

Although courts imposed restrictions in cases involving both lesbian mothers and gay fathers, they disproportionately applied conditions on visitation or custody in gay father suits. ${ }^{148}$ Gay fathers and their advocates understood this disparate treatment as a result of the historical association of gay men with pedophilia, despite scientific evidence to the contrary. Although courts throughout the country imposed restrictions on gay fathers in the 1970s and early 1980s, by the late 1980s this occurred primarily in Southern states and continued as late as 1998, the last year in the data set for this article. ${ }^{149}$ Courts also instituted conditions in cases in which they did not fear that the

143. "Washington State Lesbian Mother Wins Custody"; "Colorado Judge Rules Mother's Lesbianism Is Bar to Good Parenting," Advocate, June 12, 1980, Box 174, Folder 18, Lyon/Martin Papers; and Clark, "Activist Lesbian Mother Wins N.J. Custody Battle."

144. J.L.P. v. D.J.P., 643 S.W.2d 865, 872 (Mo. Ct. App. 1982); and "Court Uses Live-in Lover to Deny Custody," Gay Community News, January 19-25, 1992, Box 105, Folder 14, Lyon/Martin Papers.

145. Price, Draft of Lesbian Mother Case Summary, 9, 33.

146. Hertzler v. Hertzler, 908 P.2d 946, 949, 951 (Wyo. 1996).

147. National Center for Lesbian Rights, "Hertzler v. Hertzler," NCLR Newsletter, 1995, Box 1, Folder 34, Wendell Ricketts Papers, Collection Number 7681, Carl A. Kroch Library, Cornell University, 8.

148. "Gay Appeals Child Visitation Restrictions," January 1981, Child Custody Subject File, ONE; Pascarella v. Pascarella, 512 A.2d 715, 717 (Pa. Super. Ct. 1986); Birdsall v. Birdsall, 197 Cal. App. 3d 1024, 1030 (1988); and J.P. v. P.W., 772 S.W.2d 786, 793-94 (Mo. Ct. App. 1989).

149. Ex parte D.W.W., 717 So.2d 794, 796 (Ala. 1998); M. Jane Taylor, "Georgia Judge Rules Against Mom," Washington Blade, June 26, 1998, Box 105, Folder 16, Lyon/Martin 
child would become homosexual, but were concerned about other psychological effects of the child's exposure to a same-sex relationship. ${ }^{150}$

\section{A. Anti-Gay and Lesbian Parenting Research}

Although the court cases did not rely upon conservative anti-gay and lesbian parenting studies, this research emerged in part as a response to custody cases. After liberal researchers began publishing studies highlighting the similarities between children raised by heterosexual and homosexual parents, and courts on the East and West coasts based their decisions on this expert evidence, conservative psychologists engaged in scholarship to establish the opposite. The anti-gay parenting studies of the mid and late 1980s were primarily the work of Dr. Paul Cameron, a controversial psychologist. First known for his studies on the health effects of secondhand smoke, Cameron began applying his methodology to issues of sexuality in the 1970s. Cameron had learned from his work on secondhand smoke that "it really does work to attack something not directly, not the people doing it, which is often very disheartening, but the people not doing it." Educating nonsmokers about the dangers of secondhand smoke changed how society treated smoking and smokers, with nonsmokers pressuring their smoking peers to stop; Cameron would subsequently adopt this approach in opposing homosexuality, arguing it was necessary for Americans to take a strong stance against gay and lesbian rights to prevent others from becoming homosexual. Cameron "felt fairly successful in having influenced the smoking debate," giving him confidence to apply this strategy to other social issues. ${ }^{151}$

Cameron began researching marriage and sexuality in the late 1970s, while working as a professor at the Fuller Graduate School of Psychology, part of the Fuller Theological Seminary in Pasadena, California. His findings revealed that "[t]hose who were more traditionally minded, usually more religious and not divorced," were more likely to abstain from negative behaviors such as smoking and drug use, while the opposite was true for individuals who reported having an interest in homosexual activity. Cameron, who until that time identified as very liberal and socialist, credited this research for changing his worldview. "I saw this data and it kept looking very very consistent and I realized I was full of shit. So I changed my mind. Then as time led on, I changed my mind

Papers; Marlow v. Marlow, 702 N.E.2d 733, 736 (Ind. Ct. App. 1998); J.A.D. v. F.J.D., 978 S.W.2d 336, 340 (Mo. 1998); and Smith v. Pulliam, 501 S.E.2d 898, 902 (N.C. 1998).

150. Roe v. Roe, 324 S.E.2d 691, 694 (Va. 1985).

151. Paul Cameron, interview by author, June 4, 2014. 
still more. I became more and more traditional minded, seeing the value of tradition and ... being married, all the conventional things." 152 In 1978, he published the book Sexual Gradualism, which suggested that parents allow their children to experiment with heterosexual intimacy, short of intercourse, to prevent homosexuality. ${ }^{153}$ Cameron's anti-gay ideology and research led to his election as chair of the Committee to Oppose Special Rights for Homosexuals, formed in 1982 to campaign against a proposed gay rights ordinance in Lincoln, Nebraska. ${ }^{154}$ Cameron's work with the campaign led him to found the Family Research Institute (FRI), which quickly became one of the primary producers of anti-gay research. ${ }^{155}$

Cameron's anti-homosexual work became increasingly vehement, leading to professional censure and disrepute. In 1983, the American Psychological Association expelled Cameron after he failed to cooperate in an investigation by its Committee on Scientific and Professional Ethics and Conduct, sparked by complaints that Cameron was misrepresenting research on homosexuality. ${ }^{156}$ Two years later, the American Sociological Association denounced him for "consistently misinterpret[ing] and misrepresent[ing] sociological research on sexuality, homosexuality, and lesbianism" and charged a committee with "critically evaluating and publicly responding to the work of Dr. Paul Cameron." 157 Today, Cameron proudly touts the fact that the gay magazine the Advocate nominated him as "the most dangerous man in America" in 1985, and describes himself as "the man every homosexual 'loves to hate."'158

Cameron published a number of anti-gay parenting articles in the 1980s and 1990s, almost all of which were based on a survey he conducted in 1983 and 1984 while directing the FRI. The self-administered questionnaire included 550 questions and required an estimated seventy-five minutes to

152. Ibid.

153. Paul Cameron, Sexual Gradualism: A Solution to the Sexual Dilemma of Teenagers and Young Adults (Sun Valley, CA: HumLife Publications, 1978), 36-37.

154. Southern Poverty Law Center, "Paul Cameron," http://www.splcenter.org/ get-informed/intelligence-files/profiles/paul-cameron (March 26, 2014).

155. Cameron, interview by author.

156. Letter from Max Seigel to Paul Cameron, December 2, 1983, http://psychology.ucdavis.edu/faculty_sites/rainbow/html/Cameron_apaletter.html (March 26, 2014); David Reyes and Marlene Cimons, "Gays Assail Dannemeyer for Hiring Researcher," Los Angeles Times, August 20, 1985; and Chuck Stewart, Homosexuality and the Law: A Dictionary (Santa Barbara, CA: ABC-CLIO, 2001), 222.

157. American Sociological Association, Resolution adopted August 1985, http://psychology.ucdavis.edu/faculty_sites/rainbow/html/ASA_resolution_1985.PDF (March 26, 2014)

158. Family Research Institute, About FRI: FRI Scientists, http://www.familyresearchinst. org/about/ (January 29, 2014). 
complete. ${ }^{159}$ Cameron distributed the survey to over 10,000 adults in six United States cities, with almost half returning the completed questionnaire. ${ }^{160}$ The survey included questions about sexual experiences, sexual object choice, and family structure growing up. After being asked to identify as heterosexual, bisexual, or homosexual, the next question asked respondents why they believed they "became this way." Forty-two choices followed, including "one of my parents was a homosexual" and "I was seduced by "161

Using the results of the survey, Cameron published a series of articles arguing that gays and lesbians were more likely to molest children and commit incest. ${ }^{162}$ His work identified child sexual abuse as the cause of homosexuality, and since he maintained that gay and lesbian parents were more likely to have homosexual children, he concluded that gay parents were likely to molest their children. ${ }^{163}$ Although all of Cameron's articles were fervently anti-gay, his 1986 article entitled "Child Molestation and Homosexuality" also included a media study that concluded that the media over-reported homosexual molestation. He therefore warned that "much, if not all, of the recent rash of reports of child molestation may be related to the fashions of reporting rather than actual increases." 164 Cameron's other articles claimed "homosexuality is also associated with more frequent disease" and "an abbreviated life-span"; he therefore argued that homosexuality did not have a biological basis, because "from an evolutionary perspective, if genetically driven, the trait ought to disappear." 165

Although a number of scholars critiqued Cameron's methodology and conclusions at length, the majority of the scientific community ignored his work, because his articles were published in low-ranked and non-peer-reviewed journals. ${ }^{166}$ Psychological Reports, the journal in

159. Paul Cameron, Kay Proctor, William Coburn, Jr., Nels Forde, Helen Larson, and Kirk Cameron. "Child Molestation and Homosexuality," Psychological Reports 58 (1986): 328.

160. Paul Cameron and Kirk Cameron, "Homosexual Parents," Adolescence 31, no. 124 (1996): 759-60.

161. Ibid., 760.

162. Cameron, Proctor, Corburn, Forde, Larson, and Cameron, "Child Molestation and Homosexuality," 331; and Paul Cameron and Kirk Cameron, "Does Incest Cause Homosexuality?," Psychological Reports 76 (1995): 614.

163. Paul Cameron and Kirk Cameron, "Homosexual Parents," 769-70.

164. Cameron, Proctor, Coburn, Forde, Larson, and Cameron, "Child Molestation and Homosexuality," 337.

165. Paul Cameron and Kirk Cameron, "Does Incest Cause Homosexuality?," 618.

166. Gregory M. Herek, "Bad Science in the Service of Stigma: A Critique of the Cameron Group's Survey Studies," in Stigma and Sexual Orientation: Understanding Prejudice Against Lesbians, Gay Men, and Bisexuals, ed. Gregory M. Herek (Thousand Oaks, CA: SAGE Publications, 1998), 245-47; Todd G. Morrison, "Children of Homosexuals and Transsexuals More Apt to be Homosexual: A Reply to Cameron," 
which Cameron's articles most often appeared, required authors to pay a publication fee. ${ }^{167}$ His work was nevertheless extremely influential in battles over gay rights, with Cameron serving as an expert witness and his research cited in numerous amicus briefs, judicial opinions, and policy hearings. ${ }^{168}$ Cameron testified in twelve to fifteen custody cases between 1979 and 2012, and consulted on approximately forty-five additional cases. ${ }^{169}$ However, as published court cases and newspaper accounts of his expert testimony have been limited to sodomy laws, anti-gay ballot initiatives, and adoption cases, it is unclear what impact Cameron had on custody determinations, although his research was central to an influential anti-gay and lesbian parenting academic article, which the Alabama Supreme Court relied upon to deny custody to a lesbian mother in $2008 .{ }^{170}$

Other conservative researchers supported Cameron's work, including George Rekers, a professor of neuropsychiatry and behavioral science at the University of South Carolina School of Medicine. Also a Southern Baptist minister, Rekers's research focused on preventing and treating homosexuality in children. ${ }^{171}$ In 1983, Rekers co-founded the Family Research Council with James Dobson and a number of other conservative Christian leaders, creating one of America's most influential right-wing lobbying organizations. ${ }^{172}$ Rekers served as an officer of the National Association for Research and Therapy of Homosexuality (NARTH), an organization devoted to conversion therapy, until he resigned in 2010 after the media reported that he had hired a gay male prostitute to accompany

Journal of Biosocial Science 39 (2007): 153-54; and Bernadette Barton, Pray the Gay Away: The Extraordinary Lives of Bible Belt Gays (New York: New York University Press, 2012), 142-43.

167. Herek, "Bad Science in the Service of Stigma," 245.

168. Family Research Institute, About FRI; Judith Stacey and Timothy J. Biblarz, “(How) Does the Sexual Orientation of Parents Matter?," American Sociological Review 66 (2001): 161; and Herek, "Bad Science in the Service of Stigma," 223-24.

169. Cameron, interview by author; and Family Research Institute, About FRI.

170. Lynn D. Wardle, "The Potential Impact of Homosexual Parenting on Children," University of Illinois Law Review (1997): 854; and J.B.F. v. J.M.F., 730 So.2d 1190, 1196 (Ala. 2008).

171. George A. Rekers, "Atypical Gender Development and Psychosocial Adjustment," Journal of Applied Behavior Analysis 10 (1977): 559-71; George A. Rekers, Shasta L. Mead, Alexander C. Rosen, and Steven L. Brigham, "Family Correlates of Male Childhood Gender Disturbance," Journal of Genetic Psychology 142 (1983): 31-42; and George A. Rekers, Mark Kings, and Alexander C. Rosen, "Long-Term Effects of Treatment for Gender Identity Disorder of Childhood," Journal of Psychology and Human Sexuality 32 (1990): 121-53.

172. Family Research Council, FAQs, http://www.frc.org/faqs (January 30, 2014). 
him on a two week trip to Europe. ${ }^{173}$ Rekers's work focused primarily on conversion therapy and raising heterosexual children, and not on the impact of gay and lesbian parents' sexual orientation on their children. Although Rekers became a central figure in promoting and defending bans on adoption by gay and lesbian parents, neither he nor his research were at issue in custody cases. However, his work generally supported Cameron's anti-gay positions by highlighting the importance of gender role modeling in early childhood. ${ }^{174}$ Like Cameron, Rekers's research provided scientific backing for conservative positions on gay and lesbian parenting, emphasizing the need for households to have male and female role models. Similarly, the work of Joseph Nicolosi, a founding member and former president of NARTH, highlighted the critical importance of a father figure for male children's psychosexual development, which bolstered Cameron's conclusions. ${ }^{175}$ Nicolosi's 1991 book continues to serve as the standard text for psychologists engaged in reparative therapy, and his work has been central to the anti-gay arguments of the Christian Right. ${ }^{176}$

In addition to Cameron's research, opponents of lesbian mother and gay father custody suits relied upon studies of single mothers and a controversial literature on the putative danger of raising children in fatherless homes. Lynn Wardle, a law professor at Brigham Young University, summarized many of these arguments in a 1997 article. Citing a number of conservative scholars for the proposition that "children generally develop best, and develop most completely, when raised by both a mother and a father and experience regular family interaction with both genders' parenting skills

173. Penn Bullock and Brandon K. Thorp, "Reporters Find Tragic Story Amid Embarrassing Scandal," CNN.com, June 10, 2011; and Personal Assistant Contract signed by George A. Rekers, March 22, 2010, http://i.cdn.turner.com/cnn/2011/US/05/23/rekers. contract1.pdf (March 26, 2014).

174. Howard v. Arkansas, CV 1999-9881 (Ark. Circuit Ct. Pulaski County Dec. 29, 2004), author's possession, 12; Howard v. Arkansas - George Rekers Fact Sheet, ACLU, October 4, 2004, https://www.aclu.org/lgbt-rights_hiv-aids/howard-v-arkansasgeorge-rekers-fact-sheet (March 26, 2014); Trial Transcript, In re Gill, No. 06-033881 FC 04 (Fla. Circuit Ct. Oct. 3, 2008), author's possession, 812; George A. Rekers, "An Empirically-Supported Rational Basis for Prohibiting Adoption, Foster Parenting, and Contested Child Custody By Any Person Residing in a Household That Includes a Homosexually-Behaving Member," St. Thomas Law Review 18 (2005-6): 325-424; and Michael S. Lundy and George A. Rekers, "Homosexuality: Development, Risks, Parental Values, and Controversies," in Handbook of Child and Adolescent Sexual Problems, ed. George A. Rekers (New York: Lexington Books, 1995), 300.

175. Joseph Nicolosi, Reparative Therapy of Male Homosexuality: A Clinical Approach (Northvale, NJ: Jason Aronson, 1991), 34.

176. Tanya Erzen, Straight to Jesus: Sexual and Christian Conversions in the Ex-Gay Movement (Berkeley: University of California Press, 2006), 144; and Herman, The Antigay Agenda, 70-71. 
during their years of childhood," he also extrapolated from research on single-mother families to identify children of lesbian mothers as more vulnerable to poverty, teen pregnancy, and dropping out of school. ${ }^{177}$ Wardle analogized homosexual relationships to extramarital affairs, arguing that children raised by lesbian mothers or gay fathers were more likely to be insecure, commit crimes, and attempt suicide. ${ }^{178}$ As a result, Wardle argued that states should adopt a rebuttable presumption against granting custody to gay and lesbian parents. ${ }^{179}$ In addition to being cited in an Alabama Supreme Court custody case denying a lesbian mother custody, Wardle also drafted Utah's regulations prohibiting gay couples from adopting or serving as foster parents. ${ }^{180}$

As part of their arguments, conservative scientists criticized pro-gay and lesbian parenting scholarship, questioning the methodology and conclusions of the studies. In this, they were aided by debates within liberal circles that emerged in the early 1990s. By 1993, psychiatrists, sociologists, and other professionals in the social sciences had conducted over a dozen studies on the impact of gay and lesbian parents on their children. ${ }^{181}$ Almost all of these were sympathetic researchers who stressed the absence of harm to children of gay and lesbian parents, attuned to the damage that their research could cause for gay and lesbian parents in custody suits. The uniform nature of the conclusions, always asserting no difference between heterosexual and homosexual parenting, led some liberal social scientists to question the studies in the early 1990s. In 1993, Philip Belcastro and a team of health researchers published an article criticizing the studies' methodology, deeming almost all of them invalid. ${ }^{182}$ They concluded that "the statement that there are no significant differences in children reared by homosexual parents versus heterosexual parents is not supported by the published research base," but also made it clear that "[t]he converse also remains unproven." 183 Others challenged the studies on theoretical grounds, arguing that findings of absolutely no difference were implausible, if only because gay and lesbian parents were more likely to create a

177. Wardle, "The Potential Impact of Homosexual Parenting on Children," 860-62.

178. Ibid., 855-56, n.115.

179. Ibid., 860, 894.

180. Stacey and Biblarz, "(How) Does the Sexual Orientation of Parents Matter?," 160.

181. Philip A. Belcastro, Theresa Gramlich, Thomas Nicholson, Jimmie Price, and Richard Wilson, "A Review of Data Based Studies Addressing the Affects of Homosexual Parenting on Children's Sexual and Social Functioning," Journal of Divorce and Remarriage 20 (1993): 109-11; and Wardle, "The Potential Impact of Homosexual Parenting on Children," 911-20.

182. Belcastro, Gramlich, Nicolson, Price, and Wilson, "A Review of Data Based Studies," 105-22.

183. Ibid., 119. 
non-homophobic home environment and be more open to their children exploring and affirming same-sex desires. ${ }^{184}$ These researchers were careful to stress that the differences were not necessarily negative, and indeed emphasized that children raised in gay and lesbian households more likely to be "more tolerant, empathic, and acceptant of others." 185 In their critique of research studies, sociologists Judith Stacey and Timothy Biblarz recognized the difficulty for researchers who identified differences between heterosexual and homosexual households, given that this information could be used to deprive gay and lesbian parents of their rights. They consequently made clear their position that "the case for granting equal rights to nonheterosexual parents should not require finding their children to be identical to those reared by heterosexuals." 186 Although these studies took a stance in favor of gay parents, conservative groups and researchers used their critiques to oppose lesbian mother and gay father custody rights, citing these liberal scholars in support of their claims. ${ }^{187}$

Anti-gay and lesbian parenting research, which was developed much later than studies supporting gay and lesbian parents, was not used as part of an organized opposition to custody cases. Whereas lesbian mothers and gay fathers had formed networks that allowed them to share expert reports, identify sympathetic lawyers, and develop successful litigation strategies, a conservative coalition to oppose gay and lesbian parents seeking custody rights never coalesced. It was not until the late 1990s, when lesbians began litigating coparent cases, that right-wing litigation groups became involved in custody disputes. These coparent cases involved women who had decided to have one partner adopt or bear a child that the couple would raise; when the relationship disintegrated, the nonbiological or nonadoptive mother would sue for custody rights.

Coparent cases rarely addressed the impact of a parent's homosexuality on a child, as both litigants were lesbians. As a result, these cases did not turn on the parents' sexual orientation, but rather on whether courts should expand the legal definition of parenthood to encompass these new family

184. Diana Baumrind, "Commentary on Sexual Orientation: Research and Social Policy Implications," Developmental Psychology 31, no. 1 (1995): 134; Stacey and Biblarz, "(How) Does the Sexual Orientation of Parents Matter?," 162-63; and Judith Stacey, interview by author, March 31, 2014.

185. Baumrind, "Commentary on Sexual Orientation," 134; and Stacey and Biblarz, "(How) Does the Sexual Orientation of Parents Matter?," 177.

186. Stacey and Biblarz, "(How) Does the Sexual Orientation of Parents Matter?," 178.

187. Lynn D. Wardle, "The Potential Impact of Homosexual Parenting on Children," 845-46; Brief of Amici Curiae Center for Arizona Policy and Pro-Family Network in Support of Respondent, Lawrence v. Texas, No. 02-102, 2003 WL 367560, at *20 (U.S. Feb. 18, 2003); and Lofton v. Sec'y of the Dep't of Children and Fam. Servs., 358 F.3d 804, 825 n.24 (11th Cir. 2004). 
structures. Conservative and religious groups such as the National Legal Foundation, the American Family Association Law Center, Concerned Women for America, the Liberty Council, the Alliance Defense Fund, and the Rocky Mountain Family Council began filing amicus briefs in coparent cases in the late 1990s, urging courts, usually without much success, to uphold traditional understandings of family. ${ }^{188}$ In at least one case, a conservative organization also represented the biological lesbian mother in her coparent dispute. ${ }^{189}$ It is unclear why these groups intervened in coparent cases, but not custody disputes, although one possible explanation is that coparent cases redefined family in a way that custody cases did not. The custody cases, despite involving a lesbian mother or gay father, were disputes between biological parents. By contrast, in coparent cases, a nonrelated adult claimed the same right as a biological parent, redefining parental authority and expanding the number of people who could claim a right to raise a child. ${ }^{190}$ In addition to opposing the redefinition of family, conservative groups also intervened to counter the "heavy judicial hand favoring the homosexual agenda," which they believed led courts to "deliberately misconstru[e] the law to reach a politically correct result." 191 The amicus briefs were thus part of a larger project to oppose gay rights, which centered on what these groups saw as judicial activism that threatened traditional values.

\section{Conclusion}

The origins of scientific research analyzing the impact of parental homosexuality on children's future sexual orientation can be traced to the lesbian mother and gay father custody cases of the mid and late 1970s. As a result of courts' questions about the psychosexual development of children raised by lesbian mothers and gay fathers, researchers of sexuality focused their studies to provide the evidence that judges sought. The needs of gay and lesbian parents helped steer the direction of scientific research, continuing the dialectic relationship between the science of sexuality and gay rights. The presence of mental health theories and experts was constant, such

188. In re Thompson, 11 S.W.3d 913, 914 (Tenn. Ct. App. 1999); V.C. v. M.J.B., 748 A.2d 539, 541 (N.J. 2000); In re E.L.M.C., 100 P.3d 546, 548 (Colo. Ct. App. 2004); K. M. v. E.G., 173 P.3d 673, 674 (Cal. 2005); Kristine H. v. Lisa R., 117 P.3d 690, 691 (Cal. 2005); Janice M. v. Margaret K., 948 A.2d 73, 74 (Md. Ct. App. 2008); and Kulstad v. Maniaci, 220 P.3d 595, 596 (Mont. 2009).

189. In re Thompson, 11 S.W.3d at 914.

190. Leslie Cooper, interview by author, March 20, 2014.

191. V.C., 748 A.2d at 546-47. 
that the relationship between mental health theories and gay rights continued throughout the 1980s and 1990s, decades after the declassification of homosexuality from the DSM. The declassification therefore did not sever the ties between mental health and gay rights, but rather led to a significant new body of research and expertise on homosexuality. The studies that came out of custody litigation would help advocates support other claims for gay rights, extending the impact of custody cases beyond individual families.

Scientists not only responded to judges' questions and the needs of gay and lesbian litigants, but also helped shape the development of family law. For courts willing to consider lesbian mother and gay father petitions, scientific research provided evidence that justified granting custody to homosexual parents. Scientific studies helped some courts embrace a new normative commitment that rendered homosexual and heterosexual parents equally fit. Not all courts responded to research developments by embracing gay parental rights, particularly in regions where judges invoked morality and common sense in making their determinations. However, as the number of research studies increased, professional mental health associations took stances in favor of gay parents, and the gay rights movement reshaped public perception of gays and lesbians, social scientific research became more prevalent in contests over gay rights, and led conservative scholars to conduct opposing studies.

By helping to transform judicial norms in favor of gay and lesbian parents, the research studies inaugurated a new era in queer legal history. For much of the twentieth century, gays and lesbians were excluded from judicial decisions that protected sexual freedom. ${ }^{192}$ Although courts in gay and lesbian custody cases were not asserting litigants' right to sexual expression, by upholding the rights of gay fathers and lesbian mothers, the custody decisions made it clear that gay men and women did not have to choose between their sexual identity and their children. This was the beginning of a larger legal shift towards protecting the rights of gays and lesbians, which would include striking down sodomy laws and affirming the right to same-sex marriage. Although the custody awards were based on a heteronormative mindset that required gay parents to prove their sexual orientation would not result in their children growing up to be gay themselves, thereby characterizing homosexuality as an inherently negative trait, they nevertheless propelled a shift in legal norms.

This legal change would not have been possible without scientific studies, demonstrating the interrelationship between science and the law. Gay rights advocates were not the first to deploy social science research to

192. Kornbluh, “Queer Legal History,” 539-40; and Stein, Sexual Injustice, 28. 
change legal norms, but were rather drawing on a long history that had begun during the Progressive Era, a period that marked a judicial shift from formalism to realism. ${ }^{193}$ In the 1950 s and 1960 s, social science evidence became crucial to civil rights litigation, establishing patterns of discrimination on the basis of race. In relying upon scientific studies to support their claims, gay and lesbian parents were not developing a novel litigation strategy, but rather were applying a tested practice to a new claim. In doing so, however, gay fathers and lesbian mothers helped create a body of scientific evidence that reshaped judicial norms. The judicial acceptance of lesbian mothers and gay fathers as fit parents would have significant repercussions in later legal battles, particularly those over samesex marriage, in which advocates argued that marriage equality was necessary to protect the children of gay and lesbian couples. ${ }^{194}$ Gay father and lesbian mother custody cases, and the scientific research they spurred, thus provided the foundation for a larger social movement and a transformation of family law.

193. Rublin, "The Role of Social Science in Judicial Decision Making," 184.

194. Ball, Same Sex Marriage and Children, 123-24. 